Yeshiva University, Cardozo School of Law

LARC @ Cardozo Law

Articles

Faculty

Spring 1982

\title{
Towards Neutral Principles in the Administration of Criminal Justice: A Critique of Supreme Court Decisions Sanctioning the Plea Bargaining Process
}

Malvina Halberstam

Benjamin N. Cardozo School of Law, halbrstm@yu.edu

Follow this and additional works at: https://larc.cardozo.yu.edu/faculty-articles

Part of the Criminal Law Commons, and the Criminal Procedure Commons

\section{Recommended Citation}

Malvina Halberstam, Towards Neutral Principles in the Administration of Criminal Justice: A Critique of Supreme Court Decisions Sanctioning the Plea Bargaining Process, 73 Journal of Criminal Law and Criminology 1 (1982).

Available at: https://larc.cardozo.yu.edu/faculty-articles/349

This Article is brought to you for free and open access by the Faculty at LARC @ Cardozo Law. It has been accepted for inclusion in Articles by an authorized administrator of LARC @ Cardozo Law. For more information, please contact larc@yu.edu. 


\title{
CRIMINAL LAW
}

\section{TOWARDS NEUTRAL PRINCIPLES IN THE ADMINISTRATION OF CRIMINAL JUSTICE: A CRITIQUE OF SUPREME COURT DECISIONS SANCTIONING THE PLEA BARGAINING PROCESS}

\author{
MALVINA HALBERSTAM*
}

\begin{abstract}
"The history of American freedom is, in no small measure, the history of procedure."1
"The methods we employ in the enforcement of our criminal law have aptly been called the measures by which the quality of our civilization may be judged."2
\end{abstract}

\section{INTRODUCTION}

The United States Constitution provides greater procedural safeguards for the protection of individuals charged with crime than most other legally binding documents of comparable scope. ${ }^{3}$ Decisions of the

* Malvina Halberstam (Guggenheim), Professor of Law, Benjamin N. Cardozo School of Law, Yeshiva University. I wish to express my appreciation to Professors Kent Greenawalt, Gerald Gunther and Louis Lusky, and to my colleagues, Professors David Rudenstine, Paul Shupack and Telford Taylor, for their thoughtful comments on an earlier draft of this article; also to my students, Sandra Feurstein, Lawrence Spille and Peter Shapiro for their research assistance at various stages in the preparation of this article.

1 Malinski v. New York, 324 U.S. 401, 414 (1945) (separate opinion of Frankfurter, J.).

2 Coppedge v. United States, 369 U.S. 438, 449 (1962) (Warren, C.J.).

3 England, which provides similar safeguards, has no written constitution. The constitution of the Federal Republic of Germany, promulgated into law in 1949, contains several provisions that are analogous ir, scope to protections guaranteed to criminal defendants by the Bill of Rights. See 5 A. Blaustein \& G. Flanz, Constitutions of The Countries of THE WORLD (1981). (Federal Republic of Germany). For example, see article 13 which guarantees the inviolability of the home and mandates certain procedures for searches; article 103, which provides basic entitlements to process; for example, access to the courts, bans on double jeopardy and ex post facto prosecutions; and article 104, which enumerates the criminal defendant's fundamental legal rights as to the initial phases of the criminal prosecution. Absent, however, are provisions guaranteeing the right to counsel, and freedom from self-incrim- 
Supreme Court have broadly interpreted these provisions, have made most of them applicable to the states through the fourteenth amendment, and have expanded the writ of habeas corpus to provide federal review of alleged violations by the states. However, notwithstanding the broad interpretation given to the provisions of the Bill of Rights and to the fourteenth amendment, or perhaps because of it, ${ }^{4}$ the vast majority of persons charged and convicted in the United States do not enjoy most of these rights; indeed, they do not even receive a trial. Over ninety percent ${ }^{5}$ of those convicted in the United States forfeit the right to trial, ${ }^{6}$ the right to be confronted by the witnesses against them, ${ }^{7}$ the right to compulsory process for obtaining witnesses in their favor, ${ }^{8}$ and the right not to incriminate oneself. ${ }^{9}$ They plead guilty. ${ }^{10}$ In many instances, pleas of guilty are the culmination of a process in which defendants are threatened with harsh penalties if they go to trial and are promised more lenient sentences if they plead guilty. ${ }^{11}$ Nevertheless, the Supreme

ination. The Soviet constitution speaks of the citizen's duties to the state and does not provide, even in theory, guarantees to protect the individual from the state. See L. HENKIN, Human Rights Today 66-69 (1978). See also Guggenheim, Book Review, 18 Colum. J. INT'L L. 309, 311-12 (1979). The Universal Declaration of Human Rights, while proclaiming a broad array of individual rights, is not legally binding on states, and the Covenant on Civil and Political Rights, though legally binding, lacks machinery for effective implementation. The European Convention on Human Rights includes most of the rights provided for in the Bill of Rights as well as other rights and has provided machinery for their effective implementation. For a discussion of the European Convention, see Waldock, The Effectiveness of the System Set Up by the European Convention on Human Rights, 1 Human Rights L.J. 1 (1980).

4 See Alschuler, Plea Bargaining and Its History, 13 Law \& Soc. Rev. 211, 240-41 (1979); Langbein, Torture and Plea Bargaining, 46 U. CHI. L. REv. 3 (1978); Langbein, Land Without Plea Bargaining: How The Germans Do It, 78 MiCH. L. REv. 204, 205 (1979). The position that if rules designed to protect those accused of a crime from improper conviction become so extreme as to make it impossible (or almost impossible) to convict, regardless of the accused's guilt or innocence, other devices will be found to obviate these rules, is supported by Damaška's finding that the use of torture to obtain a confession developed during the Inquisition as a result of a rule of evidence that required the testimony of two unimpeachable eye witnesses or the accused's confession for conviction. See Damaška, Evidentiary Barriers to Conviction and Two Models of Criminal Procedure: A Comparative Study, 121 U. PA. L. REv. 506, 515 n.10, 586 n.214 (1972).

5 See H. Miller, W. MaDonald \& J. Cramer, Plea Bargaining in the United STATES 21-23 (1978) [hereinafter cited as MILLER]. In some jurisdictions the figure is as high as 99\%. Id. at 32 (app. A); see also Langbein, Torture and Plea Bargaining, supra note 4, at 9 n.11.

6 See U.S. CoNST. amend. VI.

7 Id.

$8 \mathrm{Id}$.

9 See U.S. CONST. amend. V.

10 See, e.g., Miller, supra note 5, at 226; A. Rosett \& D. Cressey, Justice by Consent 156 (1976); Note, The Unconstitutionality of Plea Bargaining, 83 HARV. L. REv. 1387 (1970). "[T]he primary purpose of plea bargaining is to assure that the jury trial system established by the Constitution is seldom utilized." Id. at 1389.

11 See notes 41-43 \& accompanying text infra.

There are, of course, situations in which acceptance of a plea to a lesser charge than the offense of which the accused is technically guilty, or the imposition of a lesser penalty than 
Court has rejected challenges to the constitutionality of this process in every case that has come before it. ${ }^{12}$

While the desirability of plea bargaining is open to question on a number of grounds, ${ }^{13}$ the focus of this article is not on the evils of plea bargaining (though some are discussed), but on the Supreme Court decisions rejecting challenges to the plea bargaining process. The Court's decisions in this area contravene fundamental principles of constitutional law and are inconsistent with its decisions in cases that do not involve the viability of the plea bargaining process. Thus, the Court has ruled that an admission of guilt induced by threats and promises is involuntary and may not be used to convict a defendant at trial ${ }^{14}$ but has ruled that an admission of guilt induced by threats ${ }^{15}$ and promises $^{16}$ is

that charge would require, may be justified by independent considerations, quite apart from the fact that the accused entered a plea rather than invoking his right to trial. See, e.g., Taylor, Book Review, 77 YALE L.J. 568 (1967). This article is addressed only to those situations in which the prosecution agrees to accept a plea to a lesser charge or to recommend a lower sentence in order to induce the defendant to forego a trial. $C f$. Bordenkircher $\mathbf{v}$. Hayes, 434 U.S. 357, 371 n.2 (1978) (Powell, J., concurring) (a strategy to discourage the defendant from exercising his constitutional rights).

12 It has rejected challenges to the process itself, made on the ground that the use of threats and promises to induce guilty pleas and the imposition of harsh penalties on those who refuse to plead and are convicted after trial violates the constitution. However, the Court has reversed convictions based on guilty pleas where the challenge did not threaten the continued validity of the plea bargaining process. Thus, it reversed convictions based on guilty pleas where the trial court did not comply with the requirements of Rule 11 of the Federal Rules of Criminal Procedure, McCarthy v. United States, 394 U.S. 459 (1969), or where it was not clear from the record that the accused understood all the elements of the charge and the consequence of his plea, Boykin v. Alabama, 395 U.S. 238 (1969), or where the state did not keep its sentencing promise, Blackledge v. Allison, 431 U.S. 63 (1977); Santobello v. New York, 404 U.S. 257 (1971).

13 Foremost is the questionable morality of subjecting someone to many years in prison or to life imprisonment, rather than to probation or a short prison term, or of subjecting someone to the death penalty rather than to imprisonment, because he chose to have the question of guilt determined by an impartial fact finder. The purpose of punishment, whether it be viewed as deterrence, rehabilitation, restraint, vengeance, or a combination of these, provides no basis for imposing a greater penalty on one convicted after trial than on one who pleads. (For a discussion of the argument that one who pleads is a better prospect for rehabilitation, see notes 77-82 \& accompanying text infra). The plea bargaining process also leads to sloppy investigation and preparation by defense counsel and prosecutors, see $\mathbf{M}$. RUBINSTEIN, $\mathbf{S}$. Clarke, \& T. White, Alaska Bans Plea Bargaining 10, 11, 222 (1980) [hereinafter cited as ALASKA STUDY], and fosters cynicism for the law among those charged, the victims of crime and the public. See note 273 infra. One commentator described the plea bargaining system as "a constant source of injustice" which causes some defendants "to plead guilty when they are not guilty," "allows other defendants far too lenient treatment," "causes prosecutors to overcharge" and "to lobby constantly in the legislatures for higher sentences," and "prevents rationality in sentencing." Kaplan, American Merchandising and the Guilty Plea: Replacing the Bazaar with the Department Store, 5 AM. J. CRIM. L. 215, 217 (1977). See also notes 223, 273 infra.

14 See, e.g., Spano v. New York, 360 U.S. 315 (1959).

15 North Carolina v. Alford, 400 U.S. 25 (1970).

16 Santobello v. New York, 404 U.S. 257 (1971). 
voluntary and may be used to convict a defendant without trial; that waiver of a right to appeal, induced by fear of the death penalty, is not a "knowing and intelligent" waiver, ${ }^{17}$ but waiver of the right to trial, induced by fear of the death penalty, is a "knowing and intelligent" waiver; ${ }^{18}$ that imposition of a harsher sentence following an appeal violates due process, ${ }^{19}$ since it may be motivated by a desire to discourage lawful appeals, but imposition of a harsher sentence following a trial does not violate due process even if it is clear beyond peradventure that it is motivated by a desire to discourage lawful trials; ${ }^{20}$ that a trial conviction based in part on incriminating admissions induced by a prior illegal confession is invalid, ${ }^{21}$ but a conviction following a guilty plea induced by a prior illegal confession is valid $;^{22}$ and that racial discrimination in the selection of the grand jury which issued the indictment requires reversal of a conviction following a trial, ${ }^{23}$ but does not require reversal of a conviction based on a guilty plea. ${ }^{24}$

In order to sustain the plea bargaining process, the Court has engaged in constitutional interpretation that is analytically untenable. It has failed to apply constitutional principles, some well established and others recently declared, even while purporting to reaffirm them. It has, in sum, sought to justify a result, rather than to apply neutral principles to the determination of the issue before it. This article compares the Court's reasoning in plea bargaining cases with its reasoning in non-plea bargaining cases that involve the same legal principles. It analyzes the Court's arguments for sustaining guilty pleas induced by fear of the death penalty or by promises of leniency, and for sanctioning the imposition of harsher penalties on those who reject prosecutional offers to plead and insist on a trial. Finally, it briefly addresses the contention that the system for the administration of criminal justice in the United States could not function if use of a sentencing differential to induce guilty pleas were prohibited. ${ }^{25}$

17 Fay v. Noia, 372 U.S. 391 (1963).

18 Brady v. United States, 397 U.S. 742 (1970).

19 North Carolina v. Pearce, 395 U.S. 711 (1969).

20 Bordenkircher v. Hayes, 434 U.S. 357 (1978).

21 Harrison v. United States, 392 U.S. 219 (1968).

22 McMann v. Richardson, 397 U.S. 759 (1970).

23 See, e.g., Alexander v. Louisiana, 405 U.S. 625 (1972); Peters v. Kiff, 407 U.S. 493 (1972); Cassell v. Texas, 339 U.S. 282 (1950).

24 Tollett v. Henderson, 411 U.S. 258 (1973).

25 Agreements by the prosecutor to lower or dismiss the charges against a defendant or to make sentencing recommendations in exchange for something other than a guilty plea by the defendant, such as the defendant's agreeing to testify against someone else or to provide the government with vital information, although usually accompanied by guilty pleas, involve different considerations, not addressed by this article. 


\section{INCONSISTENT INTERPRETATION OF CONSTITUTIONAL RIGHTS}

A. SOME EXAMPLES

\section{(1) Penalizing the Exercise of Constitutional Rights: Pearce, Perry, Bordenkircher and Corbitt}

The principle that one may not be penalized for exercising constitutional rights has been asserted by the Court in numerous cases. It has been invoked to preclude civil as well as criminal sanctions, and to prohibit not only governmental conduct that actually penalizes the exercise of constitutional rights, but also to prohibit governmental conduct that even appears to do so, lest there be a "chilling" effect on the exercise of rights guaranteed by the constitution. ${ }^{26}$

In North Carolina v. Pearce, ${ }^{27}$ the Court invoked this principle to protect the defendant's right to appeal. ${ }^{28}$ Pearce had been convicted of assault with intent to rape and sentenced to a term of twelve to fifteen years. His conviction was reversed by the North Carolina Supreme Court. Following another trial and conviction, he was sentenced to eight years, which, together with the years he had already served, constituted a longer sentence than that originally imposed. The Court held that absent "conduct [by] the defendant occurring after . . . the original sentencing proceeding" justifying the additional punishment, the imposition of a longer sentence following a successful appeal violated due process. ${ }^{29}$ The Court stated:

It can hardly be doubted that it would be a flagrant violation of the Fourteenth Amendment for a state trial court to follow an announced practice of imposing a heavier sentence upon every reconvicted defendant for the explicit purpose of punishing the defendant for his having succeeded in getting his original conviction set aside. Where ... the original conviction has been set aside because of a constitutional error, the imposition of such a punishment, penalizing those who choose to exercise constitutional rights, would be patently unconstitutional. And the very threat inherent in the existence of such a punitive policy would, with respect to those still in prison, serve to chill the exercise of basic constitutional rights. ${ }^{30}$

26 See Perry v. Sindermann, 408 U.S. 593 (1972); Shapiro v. Thompson, 394 U.S. 618 (1969); Gardner v. Broderick, 392 U.S. 273 (1968); Spevack v. Klein, 385 U.S. 511 (1967); Griffin v. California, 380 U.S. 609 (1965); Adamson v. California, 332 U.S. 46 (1947). See also Carter v. Kentucky, 450 U.S. 288(1981).

27395 U.S. 711 (1969).

28 The Constitution does not provide for a right to appeal and the Court has never held that states are required to provide appellate review, as the majority opinion in Pearce noted. Id. at 724. The Court has held that if a state provides appellate review the equal protection clause requires that an indigent defendant be provided with a free transcript, Griffin v. Illinois, 351 U.S. 12 (1956), and with appointed counsel for the first appeal, Douglas v. California, 372 U.S. 353 (1963).

29395 U.S. at 726.

$30 \mathrm{Id}$. at $723-24$ (citations omitted). 
While the state offered no justification for the longer sentence in Pearce, ${ }^{31}$ there was no evidence that it was motivated by vindictiveness. ${ }^{32}$ Nevertheless, the Court held that the longer sentence was unconstitutional. Reasoning that fear of vindictiveness might deter others from asserting their legal rights, a majority held that the imposition of a harsher sentence following reconviction, violates due process even absent vindictiveness. ${ }^{33}$ Justice Stewart, writing for the majority, stated:

Due process of law, then, requires that vindictiveness against a defendant for having successfully attacked his first conviction must play no part in the sentence he receives after a new trial. And since the fear of such vindictiveness may unconstitutionally deter a defendant's exercise of the right to appeal or collaterally attack his first conviction, due process also requires that a defendant be freed of apprehension of such a retaliatory motivation on the part of the sentencing judge. ${ }^{34}$

The principle that one may not be penalized for invoking one's legal rights $^{35}$ was reaffirmed and extended by the Burger Court in Blackledge $v$. Perry ${ }^{36}$ At issue was the constitutionality of the defendant's felony prosecution in a North Carolina state court of general jurisdiction following his request for a trial de novo after conviction of a misdemeanor in a state court of limited jurisdiction.

$31 \mathrm{Id}$. at 726. A longer sentence following retrial may be due to factors other than vindictiveness, such as different sentencing philosophies of different judges. Studies have shown that there is a great deal of sentencing discrepancy even for the same crime in the same court. See, e.g., Seymour, The Meaning of Disparities in Sentencing, reprinted in 2 L. RADziNowicz \& M. WOlfGANG, CRIME \& JUSTICE 373 (2d rev. ed. 1977); Frankel, Lawlessness in Sentencing, 41 U. Cin. L. Rev. 1, 7 (1972) and authorities cited therein. The judge who sentenced Pearce after the second conviction was not the same judge who sentenced him the first time.

32 " $[\mathrm{T}]$ here is not a line of evidence to support the slightest inference that the trial judge wanted or intended to punish Pearce for seeking post-conviction relief." 395 U.S. at 740 (Black, J., concurring in part and dissenting in part).

33 Id. at 725. The Court was unanimous that it would violate the Constitution to impose a greater penalty on a defendant solely because he sought appellate review. Justice Black concurred in part and dissented in part because there was no evidence that that had occurred in this case and he did not agree that due process barred a longer sentence in the absence of a showing that it was based on such an impermissible motivation. See note 32 supra. Justice Harlan was of the view that the imposition of a longer sentence following reversal on appeal was barred by the double jeopardy clause, rather than by the due process clause. Id. at 75051.

34395 U.S. at 725 . In subsequent cases the Court held that a longer sentence is not barred if there is no likelihood of judicial vindictiveness, as where the second sentence is imposed by a court with a broader jurisdiction following a trial de novo, see Colten v. Kentucky, 407 U.S. 104 (1972); but see Blackledge v. Perry, 417 U.S. 21 (1974); or where the second sentence is imposed by a jury unaware of the original sentence, see Chaffin v. Stynchcombe, 412 U.S. 17 (1973). Note, however, that Chaffin was a five to four decision and that the majority opinion relied on the plea bargaining cases.

35 The principle was qualified in Chaffin v. Stynchcombe. The Court stated in a footnote: "i iff the only objective of a stale practice is to discourage the assertion of constitutional rights it is 'patently unconstitutional.' " 412 U.S. at 32 n.10 (emphasis added) (citations omitted).

36417 U.S. 21 (1974). 
North Garolina law provides for trial of misdemeanors by a summary procedure in a court of limited jurisdiction, but gives one convicted in this manner an absolute right to a trial de novo in a court of general jurisdiction; no allegation of error is required. The prior conviction is annulled and both sides begin anew. ${ }^{37}$ Perry was convicted of assault with a deadly weapon, a misdemeanor, in a state court of limited jurisdiction under a summary proceeding. He invoked the right to trial de novo, was indicted for assault with a deadly weapon with intent to kill, a felony, and eventually pleaded guilty to the felony charge. Relying on Pearce, the Court held that the felony prosecution violated due process. It reasoned:

A prosecutor clearly has a considerable stake in discouraging convicted misdemeanants from appealing and thus obtaining a trial de novo in the Superior Court, since such an appeal will clearly require increased expenditures of prosecutorial resources before the defendant's conviction becomes final, and may even result in a formerly convicted defendant's going free. And, if the prosecutor has the means readily at hand to discourage such appeals - by "upping the ante" through a felony indictment whenever a convicted misdemeanant pursues his statutory appellate remedy-the State can insure that only the most hardy defendants will brave the hazards of a de novo trial. ${ }^{38}$

Again, the Court emphasized that evidence of actual vindictiveness is not necessary; the existence of "opportunities for vindictiveness" is sufficient. It stated:

There is, of course, no evidence that the prosecutor in this case acted in bad faith or maliciously in seeking a felony indictment against Perry. The rationale of our judgment in the Pearce case, however, was not grounded upon the proposition that actual retaliatory motivation must inevitably exist. Rather, we emphasized that "since the fear of such vindictiveness may unconstitutionally deter a defendant's exercise of the right to appeal or collaterally attack his first conviction, due process also requires that a defendant be freed of apprehension of such a retaliatory motivation on the part of the sentencing judge." We think it clear that the same considerations apply here. A person convicted of an offense is entitled to pursue his statutory right to a trial de novo, without apprehension that the State will retaliate by substituting a more serious charge for the original one, thus subjecting him to a significantly increased potential period of incarceration. ${ }^{39}$

On the reasoning and language of these cases, the plea bargaining process would seem to be a clear violation of due process. To paraphrase the Court in Perry, "the prosecution clearly has a considerable stake in discouraging [persons charged with crime from asserting their

37 Id. at 27.

$38 \mathrm{Id}$. at 27-28.

$39 \mathrm{Id}$. at 28 (citations omitted). 
right to trial], since [demand for trial] will clearly require increased expenditures of prosecutorial resources and may even result in . . . a defendant's going free."40 As part of the plea bargaining process prosecutors threaten longer sentences or higher charges if the accused refuses to plead guilty. ${ }^{41}$ A substantial number of judges follow a practice of imposing greater penalties on those who insist on a trial; some judges openly admit to such a practice. ${ }^{42}$ The existence of a significant sentencing differential, depending on whether the conviction is the result of a plea or trial, is generally accepted and well documented.43 However, the Court has refused to apply to the plea bargaining process the principle that the assertion of legal rights may not be penalized.

In Bordenkircher v. Hayes, ${ }^{44}$ the prosecutor conceded that he "upped the ante" to induce the defendant to forfeit a right. Moreover, the right involved was the fifth amendment right to trial, rather than a state statutory right to appeal or to a trial de novo. Nevertheless the Supreme

40 See text accompanying note 38 supra. Indeed, the assumption that substantial additional resources would be needed if plea bargaining were prohibited is the primary argument for sanctioning the practice. See notes 195-200 \& accompanying text infra. For a discussion of the validity of that assumption, see notes 201-23 \& accompanying text infra. For a discussion of a statistical study of federal convictions which concludes that one-third of those who plead guilty would not be convicted after trial, see notes 188-89 \& accompanying text infra.

41 See Bordenkircher v. Hayes, 434 U.S. 357 (1978), discussed at note 45 infra; Frank v. Blackburn, 610 F.2d 383 (5th Cir. 1980).

42 See, e.g., Miller, supra note 5, at 156. The Miller study found "direct evidence" of differential sentencing in "three fourths of the jurisdictions studied." Id. at xii. "Behind this practice . . . is an attitude that differential sentencing is a proper way to encourage defendants to plead guilty, thereby expediting the flow of cases. This position was disguised or not admitted by some judges; others were frank in upholding the practice." Id. One judge is quoted as saying: "he takes some of my time and I'll take some of his." Id. at 217. The ALASKA STUDY described a judge who "characterized the decision to go to trial as a conscious gamble undertaken by the defendant and saw nothing wrong in making a loser pay the price." AlaSKa STUDY, supra note 13, at 92. Apparently, probation officers also make different sentencing recommendations depending on whether the accused pled guilty or was convicted after trial. See Harris v. United States, 635 F.2d 526 (6th Cir.), cert. denied, 451 U.S. 989 (1981).

43 See annual Report of the Director of the Administrative Office of the United States CourTs 484-91 (Table D-7) (1980). Hans Zeisel "measured" the sentence differential by comparing the sentences offered to defendants who refused to plead with the sentences they received after trial. In cases that involved substantial prison terms, he found that "the average increase of the eventual over the offered sentence was $61 \%$." In the lower sentencing ranges, "the average sentence increases somewhat over $200 \%$." Moreover, as he noted, these figures are likely to be on the low side, since they are based on cases in which the defendants refused to plead, at least in some instances "because the difference between the offered guilty plea and the expected sentence after trial was too small." Zeisel, The Anatomy of Law Enforcement, in The Criminal Justice System 561 (F. Zimring \& R. Frase eds. 1981). The Supreme Court is obviously aware that a sentencing differential exists. The Court stated in Chaffin, "[u]nlike the guilty-plea situation . . . the likelihood of actually receiving a harsher sentence [if the convicted defendant appeals] is quite remote . . ." 412 U.S. 17, at 33. See generally authorities cited in note $\mathbf{4 2}$ supra.

44434 U.S. 357 (1978). 
Court held that due process had not been violated. Hayes was charged with forging a check for $\$ 88.30$, an offense punishable by a term of two to ten years. The prosecutor offered to recommend a term of five years if Hayes pleaded guilty to the charge, but threatened to indict him as a multiple offender, which would subject Hayes to a mandatory life sentence, if he insisted on a trial. ${ }^{45}$ When Hayes refused to plead, the prosecutor proceeded to make good his threat; Hayes was indicted and convicted as a multiple offender and sentenced to life imprisonment. The United States Court of Appeals for the Sixth Circuit held the habitual offender conviction invalid. Citing Pearce and Perry, the court stated, "we hold that a similar potential for impermissable vindictiveness exists when a prosecutor is allowed to bring an habitual offender indictment against a defendant who has refused to plead guilty to an indictment for the same unenhanced substantive offense." 46

The Supreme Court reversed the court of appeals and affirmed the habitual offender conviction and life sentence. Writing for the Court, Justice Stewart, who had written the majority opinions in Pearce and Perry, stated:

It may be helpful to clarify at the outset the nature of the issue in this case. While the prosecutor did not actually obtain the recidivist indictment until after the plea conferences had ended, his intention to do so was clearly expressed at the outset of the plea negotiations. Hayes was thus fully informed of the true terms of the offer when he made his decision to plead not guilty. This is not a situation, therefore, where the prosecutor without notice brought an additional and more serious charge after plea negotiations relating only to the original indictment had ended with the defendant's insistence on pleading not guilty. ${ }^{47}$

\section{Conceding that:}

To punish a person because he has done what the law plainly allows him to do is a due process violation of the most basic sort . . . and for an agent of the State to pursue a course of action whose objective is to penalize a person's reliance on his legal rights is "patently unconstitutional . . ."

Justice Stewart nevertheless concluded, "in the 'give-and-take' of plea bargaining, there is no such element of punishment or retaliation so long as the accused is free to accept or reject the prosecution's offer." 48

Surely the decision in Pearce would not have been different had the prosecutor "informed" the defendant that if he insisted on appealing and succeeded in having his conviction reversed he would be retried and

45 Hayes had two prior convictions, one in 1961 for detaining a female, and one in 1970 for robbery, id. at 359 n.3, which, under the applicable Kentucky habitual offender statute, subjected him to mandatory life imprisonment. Id. at 359 n.2.

46 Hayes v. Cowan, 547 F.2d 42, 44 (6th Cir. 1976), rehearing denied, 435 U.S. 918 (1978).

47434 U.S. at 360.

$48 \mathrm{Id}$. at 363 (citations omitted) (emphasis added). 
on reconviction he would be sentenced to a longer term. Similarly, the decision in Perry would not have been different had the prosecutor informed the defendant there that if he sought a trial de novo he would be charged with a felony. Yet in both cases the defendants would have been "free" to accept or reject the offer. While it has been argued that pleas induced by promises and threats are involuntary and for that reason invalid, ${ }^{49}$ this was not the basis of the court of appeals' holding in Bordenkircher, nor of the Supreme Court decisions in Pearce and Perry, on which the court of appeals relied. ${ }^{50}$ The point of those cases was not that the defendants were unaware that their assertion of the rights in question might result in a greater penalty, or that they were not "free to accept or reject the prosecution's offer," but that the state may not penalize the assertion of legal rights and may not even engage in conduct that appears to do so, lest it deter the legitimate assertion of such rights. The argument that the imposition of a life sentence rather than a five year term following the defendant's insistence on a trial does not violate his constitutional rights because he was "free to accept or reject the prosecutor's offer," fails to distinguish between two distinct principles: that waiver, to be valid, must be voluntary, and that one may not be penalized for asserting one's constitutional rights. Violation of either principle is sufficient to vitiate a conviction.

The Court had fused (or confused) these principles in earlier cases. ${ }^{51}$ Thus, the Court stated in Pearce:

A court is without right to ... put a price on an appeal. A defendant's exercise of a right of appeal must be free and unfettered . . . [I]t is unfair to use the great power given to the court to determine sentence to place a defendant in the dilemma of making an unfree choice. ${ }^{52}$

An even stronger example of the fusion (or confusion) of these distinct

49 See, e.g., Shelton v. United States, 242 F.2d 101 (5th Cir.), rev'd en banc, 246 F.2d 571 (1957), rev'd on confession of error by the Solicitor General, 356 U.S. 26 (1958); Alschuler, supra note 4, at 218. Cf. Bram v. United States, 168 U.S. 532, 542-43 (1897) (confession extracted "by any direct or implied promises, however slight" is involuntary). But see Enker, Perspectives on Plea Bargaining in The President's Commission on LAW Enforcement and Administration of Justice, TASK Force Report: The Courts 116 (app. A) (1967).

50 See notes 27-39 \& accompanying text supra. In distinguishing Pearce in Collen v. Kentucky, Justice White stated that the Kentucky procedure did not involve "the hazard of being penalized for seeking a new trial, which underlay the holding of Pearce . . . " 407 U.S. at 116.

51 See North Carolina v. Pearce, 395 U.S. 711; Garrity v. New Jersey, 385 U.S. 493 (1967). See also Fay v. Noia, 372 U.S. 391 (1963), discussed at notes 89-90 infra. Some members of the Court apparently view the principle that the exercise of constitutional rights may not be penalized as an aspect of voluntariness. Justice Brennan, dissenting in Parker v. North Carolina, 397 U.S. 790 (1970), stated, "[t]he legal concept of 'involuntariness' has not been narrowly defined but refers to a surrender of constitutional rights influenced by considerations that the government cannot properly introduce." Id. at 802 (Brennan, J., dissenting).

52395 U.S. at 723. 
principles is Garrity v. New Jersey, ${ }^{53}$ in which the Court held that police officers' statements, given pursuant to a state statute which provided that refusal to answer could result in job forfeiture, were involuntary. Justice Douglas, writing for the majority said:

The choice given petitioners was either to forfeit their jobs or to incriminate themselves. The option to lose their means of livelihood or to pay the penalty of self-incrimination is the antithesis of free choice to speak out or to remain silent. . . . We think the statements were infected by the coercion inherent in this scheme of questioning and cannot be sustained as voluntary under our prior decisions. ${ }^{54}$

Justice Harlan criticized the majority for its confusing analysis. $\mathrm{He}$ stated:

The majority is apparently engaged in the delicate task of riding two unruly horses at once: it is presumably arguing simultaneously that the statements were involuntary [and] . . . that they were products of an impermissible condition imposed on the constitutional privilege. These are very different contentions and require separate replies. . . . ${ }^{55}$

Since the Court held in Pearce and in Garrity that the government conduct in question violated the accused's constitutional rights, its failure to distinguish between the two principles, while analytically incorrect, did not have the effect of denying rights protected by one of these principles on the ground that the challenged conduct did not violate the other principle. ${ }^{56}$ In Bordenkircher on the other hand, the Court refuted Hayes' contention that the imposition of the longer sentence following his insistence on a trial penalized his assertion of the right to trial with the argument that his decision to demand a trial, rather than plead guilty, was voluntary.

Further, even under the rationale of Pearce and Garrity, which fused the two principles, the reasoning of Bordenkircher is fallacious. The argument that Hayes had a free choice necessarily rejects the position that placing an accused in the dilemma of having to choose between exercis-

53385 U.S. 493 (1967).

$54 \mathrm{Id}$. at $497-98$.

$55 \mathrm{Id}$. at 501 (emphasis added).

56 On the contrary, it may have had the effect of bringing within the ambit of constitutional protection claims that were not entitled to such protection. Under Justice Harlan's analysis, the question in Garrily was not one of voluntariness, since the statements were clearly voluntary, 385 U.S. at 506, but whether "the condition imposed by the State" on the exercise of the constitutional rights in question "serve[d] in itself to render the statements inadmissible." Id. This in turn devolved into two questions: "whether consequences may properly be permitted to result to a claimant after his invocation of the constitutional privilege, and if so, whether the consequence in question is permissible." Id. at 507 . With respect to the privilege against self-incrimination, which was at issue in Garrity and Spevack, Justice Harlan concluded, "in my view nothing in the logic or purposes of the privilege demands that all consequences which may result from a witness' silence be forbidden merely because that silence is privileged." Id. 
ing his constitutional rights and subjecting himself to a higher penalty renders the choice involuntary, since Hayes faced that dilemma. Yet, it was this broad definition of voluntariness that permitted the Court to fuse the two principles in Garrity in the first place and to hold that the police officers' statements were involuntary. Thus, whether one distinguishes between the two principles as Justice Harlan did, or one merges the two principles by characterizing acts done to avoid a penalty as involuntary, as the Court did in Garrity and Pearce, the argument in Bordenkircher that the imposition of a higher sentence following the defendant's refusal to plead guilty did not contravene his constitutional rights because he was free to choose is contrary to both precedent and logic.

Justice Stewart also argued in Bordenkircher that "the due process violation in cases such as Pearce and Perry lay not in the possibility that a defendant might be deterred from the exercise of a legal right, but rather in the danger that the state might be retaliating against the accused. . . ."57 This interpretation of Pearce and Perry is questionable in view of the Court's statements in those cases. Thus, the Court stated in Pearce that "the very threat inherent in the existence of such a punitive policy would, with respect to those still in prison, serve to chill the exercise of basic constitutional rights," that "the rationale of our judgment in Pearce" was that the fear of "vindictiveness may unconstitutionally deter a defendant's exercise of the right to appeal." 59 Moreover, even if one accepts Stewart's interpretation of Pearce and Perry, it is not apparent why imposition of a longer sentence following appeal is retaliation, whereas sentencing to a longer term following a trial is not, or why charging a defendant with a misdemeanor in a summary proceeding before a court that has no jurisdiction over felonies and charging him with a felony if he insists on a trial de novo before a court that has jurisdiction over felonies is retaliation, whereas charging him with a felony that carries a maximum of ten years if he pleads guilty and charging him with a felony that carries mandatory life imprisonment if he insists on a trial is not retaliation. Indeed, if a distinction is to be made on this last basis, Bordenkircher appears to be the clearer instance of retaliation, since the prosecutor had apparently concluded that life imprisonment was not an appropriate sentence in that

57434 U.S. at 363 (citations omitted).

58395 U.S. at 724.

59417 U.S. at 28. See also dissenting opinion of Justice Marshall in Colten v. Kentucky, 407 U.S. 104 (1972). "Pearce was based, rather, on the recognition that whenever a defendant is tried twice for the same offense, there is inherent in the situation the danger of vindictive sentencing the second time around, and that this danger will deter some defendants from seeking a second trial." 407 U.S. at 126 (emphasis added). 
case $^{60}$ and only used the threat of the life sentence as a means of inducing the defendant to plead guilty.

In Bordenkircher the retaliatory purpose was particularly clear because the prosecutor added the habitual offender charge after the defendant refused to plead and acknowledged that he did so because the defendant insisted on his right to trial. ${ }^{61}$ Where the charge subsequently dropped is included in the initial indictment it may be more difficult to prove that the prosecutor's decision to drop the charge was motivated by a strategy to discourage the defendant from exercising his constitutional rights. Analytically, however, "Bordenkircher would be no different if the grand jury had indicted Hayes as a recidivist from the outset, and the prosecutor had offered to drop that charge as part of the plea bargain," as the majority recognized. ${ }^{62}$ Thus, a contrary decision in Bordenkircher would have barred the use of charge reductions to induce guilty pleas regardless of whether the charge was included in the original indictment or added later and would have substantially undermined the plea bargaining process. ${ }^{63}$

Finally, in Corbitt v. New Jersey, ${ }^{64}$ the Court extended Bordenkircher to sustain a statutory scheme that authorized imposition of a harsher penalty on one convicted after trial than on one who entered a plea. ${ }^{65}$ Justice White, writing for the majority, stated:

While confronting a defendant with the risk of more severe punishment clearly may have a "discouraging effect on the defendant's assertion of his trial rights, the imposition of these difficult choices [is] an inevitable"-and permissible-"attribute of any legitimate system which tolerates and encourages the negotiation of pleas." 66

Rejecting the position of the concurring and dissenting justices that a

60 " $[\mathrm{H}]$ ere the prosecutor evidently made a reasonable, responsible judgment not to subject an individual to a mandatory life sentence when his only new offense had societal implications as limited as those accompanying the uttering of a single $\$ 88$ forged check and when the circumstances of his prior convictions confirmed the inappropriateness of applying the habitual criminal statute." 434 U.S. at 371 (Powell, J., dissenting).

61 Id.

62 Id. at 360-61. Justice Powell agreed that "these two situations would be alike" if the prosecution's decision to charge were "occasioned . . . by a strategy to discourage the defendant from exercising his constitutional rights" and stated, "[i]n theory, I would condemn both." However, he considered the hypothetical situation to be "largely unreviewable in practice." Id at $371 \mathrm{n} .2$.

63 Although Blackledge v. Perny involved a guilty plea, the decision invalidating it did not affect the legitimacy or continued viability of the plea bargaining process.

64439 U.S. 212 (1978).

65 The New Jersey statute made life imprisonment mandatory for a defendant convicted of first degree murder by a jury, but permitted the Court to impose a sentence of 30 years if a defendant entered a plea of nun vult. Id. at $215 \mathrm{n}$.1. Justice Stewart took the position that it is "impossible to state with any confidence that the New Jersey statute does in fact penalize a defendant's decision to plead not guilty" and concurred on that basis. Id. at 227 .

66439 U.S. at 220. 
statute which clearly provided greater penalties for those convicted after trial would be unconstitutional, the majority stated, "we cannot hold that a prosecutor may . . . offer leniency to those who plead . . . and yet hold that the legislature may not openly provide for the possibility of leniency in return for a plea."67 Clearly, the majority's reasoning, that it would be inconsistent to hold that it is constitutional for the prosecutor to use a sentencing differential to induce a guilty plea but unconstitutional for the legislature to do so, is correct. What is open to question is the majority's assertion that the Bill of Rights, as hitherto interpreted by the Supreme Court, including the Burger Court, does "tolerate", let alone "encourage", a system that has an "inevitable attribute" "confronting a defendant with the risk of more severe punishment [which] clearly may have a discouraging effect on the defendant's assertion of his trial rights." Prior to these decisions, one would have thought that the Bill of Rights does not encourage such a system, ${ }^{68}$ that acceptance of a system that has as "inevitable attribute" forcing defendants to such a choice is precluded by the principle that the imposition of a longer sentence after the defendant asserts a legal right is a violation of the Constitution, a principle unanimously accepted by the Court in Pearce. ${ }^{69}$

Some commentators ${ }^{70}$ have drawn a distinction between penalizing those who insist on a trial and extending leniency to those who plead guilty, characterizing the former practice as unethical and/or unconstitutional but finding the latter unobjectionable. The argument has surface appeal. It appears to solve the moral and constitutional dilemma inherent in plea bargaining by retaining plea bargaining without penalizing those who invoke the right to trial. However, the distinction is neither practically nor theoretically tenable. As a practical matter,

67 Id. at 224 n. 14.

68 Indeed, until quite recently, defendants, defense counsel, and prosecutors routinely went through a charade at the time the plea was taken, in which the defendant stated on the record, in response to the court's inquiry, that no promises or threats had been made to him, even though all three, and sometimes the court, knew that the plea was part of an agreement between the defendant and the prosecutor involving sentencing or charge reduction. See Enker, supra note 49 , at 111 . The defendant denied the promises or threats, generally on the instructions of his lawyer and with the acquiscence of the prosecutor, because they assumed that an admission that the guilty plea was induced by threats or promises would invalidate it. The ABA standards legitimizing the process, but requiring that it be set forth on the record, did much to change that. See ABA Standards Relating to Pleas OF Guilty $\S 1.8$ (1967). For a reference to the current version of the standards, see note 225 infra. My point is not that concealing the fact that the plea had been induced by a promise or threat was preferable, but that the assumption of even those who engaged in the process was, contrary to the Supreme Court, that a legitimate system "would not tolerate and encourage" use of threats and promises to induce guilty pleas.

69395 U.S. 711 (1969).

70 See, e.g., Nemerson, Coercive Sentencing, 64 MINN. L. REV. 669, 716-17 (1980). See also aBA Standards Relating to the Administr.4tion of Justice $§ 1.8(b)$ (1974). 
there is no "proper sentence" against which the sentence imposed in a particular case can be measured to determine whether it was more severe because the accused insisted on a trial or more lenient because he pleaded guilty. ${ }^{71}$ Moreover even if a procedure could be devised to ensure that the defendant who pleads is extended leniency rather than the converse, ${ }^{72}$ the dilemma inherent in plea bargaining would not be eliminated. It cannot be eliminated because a sentence differential is the essence of plea bargaining. Analytically, whether the sentence differential is characterized as a penalty or as a leniency, the result is the same: those who insist on a trial suffer substantially longer imprisonment than those who plead guilty. ${ }^{73}$

A sounder approach, suggested by Justice Harlan's analysis in Garrity, would be to consider "whether consequences may properly be permitted to result to a claimant after his invocation of the constitutional [right in question] and if so, whether the consequence in question is permissible."74 Assuming that attaching any consequences to the right in question is permissible, "the validity of a particular consequence depends both upon the hazards, if any, it presents to the integrity of the [right] and upon the urgency of the public interest it is designed to protect." 75 The Court has never explicitly addressed the question of whether consequences may be attached to the right to trial. Nor has the Court weighed the "hazards" that the use of a substantial sentencing differential to induce guilty pleas presents to the integrity of that right

71 "In the normal process of sentencing 'there are virtually no rules or tests or standards' ." Bullington v. Missouri, 451 U.S. 430, 443-44 (1981) (Blackmun, J.) (quoting M. Frankel, Criminal Sentences: Law Without Order 38 (1973)); Scott v. United States, 419 F.2d 264 (D.C. Cir. 1969). "The 'normal' sentence is the average sentence for all defendants, those who plead guilty and those who plead innocent. If we are 'lenient' toward the former, we are by precisely the same token 'more severe' toward the latter." Id. at 278 . See also authorities cited in note 31 supra.

72 For example, legislation could be enacted providing a specific sentence for each crime with a "discount" for a plea, or requiring that the sentencing court state the sentence it would impose, based on the facts of the crime and on the accused's record, without knowing whether the conviction was the result of a plea or a trial, and authorizing (or mandating) a lower sentence if the conviction was the result of a plea. See, e.g., Kaplan, supra note 13, at 222, suggesting that a plea of guilty should be considered a "mitigating factor" and "should reduce the sentence by 50\%." Recognizing that this "amounts to a penalty for the exercise of a constitutional right" and that "the instant reaction to such a scheme would be that it is unconstitutional," Kaplan argues [tongue in cheek?] "[a]fter all, we presently do exactly this; we pay the defendant for giving up his right to trial." In practice if sentences were determined first, then reduced for those who plead guilty, there would probably be a tendency to increase sentences generally to make sure that even after leniency is extended to those who plead-most defendants-the penalty imposed was sufficient to accomplish the purposes of the criminal law. Cf. Kaplan, supra note 13, at 217 (plea bargaining causes prosecutors "to lobby for higher sentences").

73 See notes $42-43$ \& accompanying text supra.

74385 U.S. at 507.

$75 \mathrm{Id}$. 
against the "urgency" of the public interest that the plea bargaining process is designed to protect. ${ }^{76}$

The sentencing differential has also been justified on the ground that those who plead (1) have, by admitting guilt, demonstrated repentance and greater susceptibility to rehabilitation and (2) are entitled to consideration because they save the state the expense of trial. Thus, the Supreme Court stated in Brady v. United States:

[W] cannot hold that it is unconstitutional for the State to extend a benefit to a defendant who in turn extends a substantial benefit to the State and who demonstrates by his plea that he is ready and willing to admit his crime and to enter the correctional system in a frame of mind that affords hope for success in rehabilitation over a shorter period of time than might otherwise be necessary. ${ }^{77}$

There are several difficulties with these arguments. First, there is no empirical evidence that those who plead guilty are more amenable to rehabilitation. ${ }^{78}$ Research has shown that many defendants who plead guilty continue to assert their innocence, and that few are truly con-

76 Some of the Court's decisions, such as Bordenkirscher v. Hayes, 434 U.S. 357, permitting the addition of charges and the imposition of a significantly longer sentence when the defendant refuses to plead, and some of its statements, such as in Santobello v. New York, 404 U.S. 257, 260, that it would be necessary to "multiply by many times the number of judges and court facilities" if every criminal charge were subjected to a trial, may reflect an implicit conclusion that it is permissible to attach consequences to the rights to trial and that the need for plea bargaining outweighs the hazards that use of a penalty differential presents to the right to trial. The reasoning in the decisions sanctioning the plea bargaining process was not along those lines, however. See notes 140-94 \& accompanying text infra. Moreover, it would be difficult to justify sanctioning the plea bargaining process under this analysis. Arguably, the right to trial is so fundamental that no consequences may attach to it. But, assuming that some consequences may attach to the right to trial, the imposition of a significantly longer sentence on those who invoke the right would not seem to be such a consequence. The use of a sentencing differential presents at least two hazards: that innocent persons will be convicted, see notes $177-84$ \& accompanying text infra, and that the right to trial itself will be largely eviscerated. See MiLler, supra note 5; Note, supra note 10, at 1389. (While the empirical evidence does not support the contention that if sentencing and charge concessions were prohibited, the percentage of trials would increase substantially, see notes 208-24 \& accompanying text infra, even if the increase in the number of trials as a percentage of all dispositions is small, the increase in the number of trials as a percentage of trials is significant. See note 220 infra.) The public interest to be served, against which these hazards must be balanced, is the conservation of resources that is assumed to result from plea bargaining. However, the existing empirical evidence does not support the position that substantially greater resources would be required if resort to sentencing differentials to induce guilty pleas were prohibited. See notes 201-23 \& accompanying text infra. Moreover, lack of resources has not been accepted as a justification for the denial of other constitutional rights. See notes 226-29 \& accompanying text infra.

77397 U.S. 742, 753 (1970).

78 For example, an empirical study comparing the rate of recidivism among those convicted after trial and those convicted following a guilty plea might be indicative of whether rehabilitation efforts have been more successful with the latter. The Supreme Court has cited to no evidence, nor have I found any, establishing that those who plead guilty are more amenable to rehabilitation. On the contrary, the plea bargaining process has been faulted for 
trite. ${ }^{79}$ Second, no negative implications may be drawn from the assertion of a constitutional right; just as the prosecutor may not ask the jury to infer that the accused is guilty from his failure to testify, ${ }^{80}$ so the court may not infer lack of repentance from his failure to plead guilty. ${ }^{81}$ As Judge Bazelon pointedly noted, no one has yet explained why a person who invokes his sixth amendment right to trial is any less amenable to rehabilitation than one who invokes other constitutional rights, such as his fifth amendment privilege against self-incrimination, or his fourth amendment protection against unreasonable search and seizure. ${ }^{82}$

As to the argument that the defendant is entitled to consideration for saving the state the expense of trial, it is not at all clear that plea bargaining does save the government time and money, in the long run. ${ }^{83}$ However, even if it does, that surely is not a justification for the denial of constitutional rights. Compelling a suspect to confess, searching without a warrant, wiretapping in the absence of a court order, may also save the state time and expense, but the courts have not permitted these practices. Nor would anyone suggest that the accused's sentence should

the lack of success of rehabilitation efforts. See OfFicial REPORT OF THE NEW YORK STATE Special Commission on AtTica, AtTica 30-31 (1972).

79 Only 95 out of 723 defendants questioned admitted their guilt to probation officers shortly after pleading guilty in court. See A. ROSETT \& D. CRESSEY, supra note 10, at 28. Rosett and Cressey conclude that "[d]efendants overwhelmingly plead guilty not because they repent, but to avoid or limit pain." Id . at 147. See also Alschuler, The Prosecutor's Role in Plea Bargaining, 36 U. CHI. L. Rev. 50, $57 \mathrm{n} .24$ (1968), who argues that "[t]he guilty-plea defendant is often a person who feels no qualms about confessing to his misdeeds" [whereas] "the trial defendant is often a person who feels so uncomfortable about his criminal conduct that he cannot bring himself to confess"; Baldwin \& McConville, Plea Bargaining and Plea Negotiation in England, 13 LAW \& Soc. REv. 287, 299 (1979).

80 See Griffin v. California, 380 U.S. 609 (1965). See also Carter v. Kentucky, 450 U.S. 288.

81 "I can think of no special circumstances that would justify use of a constitutional privilege to discredit or convict a person who asserts it." Grunewald v. United States, 353 U.S. 391, 425 (1957) (Black, J., concurring). Cf. Roberts v. United States, 445 U.S. 552 (1980) (the court there held that the sentencing judge properly considered as one factor in imposing sentence the defendant's refusal to cooperate by providing information about other participants in the criminal enterprise. Id. at 561). Both the majority and concurring opinions stressed, however, that the defendant's claims of the fifth amendment privilege against selfincrimination and of fear of reprisal were raised for the first time on appeal. Justice Brennan (concurring) stated, "I agree with the Court that the trial judge cannot be faulted for drawing a negative inference from petitioner's noncooperation when petitioner failed to suggest that other, neutral, inferences were available." Id. at 562 (Brennan, J., concurring). See also U.S. v. Prescott, 581 F.2d 1343, 1351 (9th Cir. 1978).

That the court may not infer lack of repentance from the accused's failure to plead would not, of course, bar it from considering favorably a genuine statement of repentance. While only one who admits guilt (before or after trial) is in a position to make such a statement, a guilty plea is not necessarily indicative of genuine repentance and the failure to plead doesn't preclude repentance.

82 See Scott v. United States, 419 F.2d 264, 270 (D.C. Cir. 1969).

83 See text accompanying notes 221-24 infra. 
depend on such factors as whether he requested a jury, moved to suppress evidence, or called witnesses on his behalf. Yet all of these affect the expense incurred by the state, and an accused who refrains from invoking these and numerous other rights "extends a substantial benefit to the State."

\section{(2) Waiver Induced by Fear of Death Penalty: Noia, Jackson, Brady, Parker and Alford}

A guilty plea constitutes a waiver of a number of constitutional rights, including the right to trial by jury, the privilege against self-incrimination, and the right to confront one's accusers. ${ }^{84}$ The Court had held some years ago, in Johnson $v$. Zerbst ${ }^{85}$ that, to be valid, a waiver must be an "intentional relinquishment of a known right." 86 More recently, in Fay v. Noia, ${ }^{87}$ the Court held that even "intentional relinquishment of a known right" may not constitute a waiver if it is done to avoid the risk of the death penalty. ${ }^{88}$ Noia and two codefendants had been convicted of murder in the first degree and sentenced to life imprisonment. The convictions were based on confessions which the defendants claimed had been coerced. Noia's codefendants appealed. The appellate court agreed that their confessions had been coerced, and the convictions were reversed. Noia, who had not appealed within the time provided by statute, sought federal habeas corpus. His petition was denied by the lower courts on the ground that his failure to appeal within the time prescribed by the New York law constituted a waiver of his right to appeal and was an "adequate state ground," precluding federal relief.

There was no question that Noia was aware of his right to appeal and that his decision not to appeal was deliberate. Nevertheless, concluding that Noia's decision not to appeal was induced by the fear that if he succeeded in getting a reversal he might be retried, reconvicted and sentenced to death, ${ }^{89}$ the Supreme Court held that no waiver had oc-

84 See, e.g., McCarthy v. United States, 394 U.S. 459, 466 (1969).

85304 U.S. 458 (1938).

86 Id. at 464. In Schneckloth v. Bustamonte, 412 U.S. 218 (1973), holding valid defendant's consent to a search even though he was not informed of his right to refuse consent, the Court limited this test to waiver of rights "constitutionally guaranteed to protect a fair trial and the reliability of the truth-determining process." Id . at 236.

87372 U.S. 391 (1963).

88 Cf. United States v. Jackson, 390 U.S. 570 (1968), holding unconstitutional a statutory provision that authorized imposition of the death penalty only if the jury so recommended, on the ground that it required the accused to assert his right to a jury at the risk of the death penalty.

89 Noia's decision not to appeal was, at most, only partially due to fear of the death penalty. At a hearing held by the district court, Noia stated that he did not appeal because he "did not wish to saddle his family with an additional financial burden and had no funds of 
curred. As Justice Brennan put it:

For Noia to have appealed in 1942 would have been to run a substantial risk of electrocution. His was the grisly choice whether to sit content with life imprisonment or to travel the uncertain avenue of appeal which, if successful, might well have led to a retrial and death sentence. ${ }^{90}$

Similarly, in United States v. Jackson, ${ }^{91}$ the Court held a provision of a federal statute which authorized imposition of the death penalty only if a jury so recommended to be unconstitutional on the ground that it required the accused to assert his right to a jury at the risk of his life. The Court stated, "the defendant's assertion of the right to jury trial may cost him his life, for the federal statute authorizes the jury-and only the jury-to return a verdict of death."92

However, in Brady v. United States, ${ }^{93}$ Parker v. North Carolina ${ }^{94}$ and North Carolina $v$. Alford, ${ }^{95}$ cases in which the defendants pleaded guilty to avoid risk of the death penalty, the Court refused to hold the waiver of the right to trial invalid, even though in each case the defendant could assert the right to trial only at the risk of his life, and was, like Noia, confronted with the "grisly choice of whether to sit content with life imprisonment" or to insist on a trial "which might well have led to a . . . death sentence."

Brady was charged with kidnapping under the same federal statute whose death penalty provision was held unconstitutional in Jackson.$^{96}$ He proceeded to trial, but, learning that a codefendant had pleaded guilty and would be available to testify against him, he, too, entered a guilty plea. ${ }^{97}$ The Court noted that "[b]ecause the trial judge was unwilling to try the case without a jury, petitioner made no serious attempt to reduce the possibility of a death penalty by waiving a jury trial." 98 While the Court seemed to question whether Brady's decision to waive trial and enter the plea was in fact induced by fear of the death penalty, ${ }^{99}$ it made clear that its doubts on that score were not the basis for

his own." 372 U.S. at 397 n.3. His lawyer testified that "Noia was also motivated not to appeal by fear that if successful he might get the death sentence if convicted on a retrial." Id. (emphasis added). Moreover, since the confession, which was the "sole evidence" against him, would, by hypothesis, have been inadmissible if he succeeded on appeal, the risk that he would be reconvicted following a successful appeal was not great.

90372 U.S. at $439,446$.

91390 U.S. 570 (1968).

92 Id. at 572.

93397 U.S. 742 (1970).

94397 U.S. 790 (1970).

95400 U.S. 25 (1970).

96390 U.S. 570 (1968). Jackson was decided after Brady had entered his guilty plea.

97397 U.S. at 743.

$98 \mathrm{Id}$.

99 In the text of the opinion the Court states, "[i]t may be that Brady, faced with a strong case against him and recognizing that his chances for acquittal were slight, preferred to plead 
its decision. The majority opinion states unequivocally, "a plea of guilty is not invalid merely because entered to avoid the possibility of a death penalty."100

Parker, a fifteen year old black, was charged with burglary in the first degree under a North Carolina statute which provided for imposition of the death penalty if the accused was convicted after trial (unless the jury recommended otherwise) and for life imprisonment if the conviction was based on a plea. ${ }^{101}$ The defendant, who had signed a confession after being held in prison overnight and interrogated without counsel, pleaded guilty. Conceding that the death penalty provision of the statute was probably unconstitutional, since it required the defendant to risk the death penalty in order to assert his right to trial, the Court nevertheless dismissed the contention that Parker's waiver of the right to trial and plea were invalid, stating that it saw "nothing to distinguish Parker's case from Brady's." 102 In neither case did the Court address the argument that if the death penalty provision was unconstitutional because fear of the death penalty might improperly induce an accused to waive the right to trial and plead guilty, then a fortiori, a guilty plea induced by fear of the death penalty must also be invalid. ${ }^{103}$

The third case, North Carolina v. Alford, ${ }^{104}$ involved a statute which, like the statute in Parker, provided for imposition of the death penalty only upon conviction following a trial. If the Court had any doubt whether Brady's or Parker's guilty plea was induced by fear of the death penalty, it could have had no doubt with respect to Alford's. When he entered the plea he told the trial court, "I just pleaded guilty because they said if I didn't they would gas me for it, and that is all . . . I'm not guilty but I plead guilty."105 The Supreme Court held Alford's plea, and, by implication, his waiver of the right to trial, valid. ${ }^{106}$

guilty and thus limit the penalty to life imprisonment rather than to elect a jury trial which could result in a death penalty." Id. at 749 . But in a footnote the Court states that this possibility "seems to have been rejected" by the district court. Id . at 749 n.7. Three Justices, Brennan, Douglas and Marshall, concurred in the result on the ground that there was "no evidence" that fear of the death penalty "played a significant role in [Brady's] decision to enter a guilty plea." Id. at 815 (Brennan, J., concurring). For a discussion of the possibility that Noia's failure to appeal involved other considerations than fear of the death penalty, see note 89 supra.

100397 U.S. at 755.

101 The statute is set forth in the Court's opinion, 397 U.S. at $792-93 \mathrm{nn} .1 \& 2$.

$102 \mathrm{Id}$. at 795.

103 See Justice Brennan's dissenting opinion in Parker v. North Carolina, 397 U.S. at 799800, 807-08.

104400 U.S. 25 (1970).

$105 \mathrm{Id}$. at $28 \mathrm{n} .2$.

$106 \mathrm{Id}$. at 39 . A contrary ruling would have had the paradoxical result of permitting a defendant who admits to murder to escape the death penalty while forcing a defendant who may be innocent to stand trial and if (wrongly) convicted face the death penalty, a paradox 
The Court in Fay v. Noia noted that not every risk of death invalidated a waiver. It stated:

This is not to say that in every case where a heavier penalty, even the death penalty, is a risk incurred by taking an appeal or otherwise foregoing a procedural right, waiver as we have defined it cannot be found. Each case must stand on its facts. In the instant case, the language of the judge in sentencing Noia . . . made the risk that Noia, if reconvicted, would be sentenced to death, palpable and indeed unusually acute. ${ }^{107}$

But the risk of death facing Brady, Parker, and Alford was no less acute than that facing Noia. ${ }^{108}$ In none of these cases did the Court rest its decision on a finding that the facts failed to establish that the risk was "palpable and acute."109 "The standard" for determining the validity of a plea, according to the Court in Alford, is "whether the plea represents a voluntary and intelligent choice among the alternative courses of action open to the defendant." 110 Contrary to Noia, in which the Court had held that a choice induced by "palpable" and "acute" fear of death cannot be voluntary and intelligent, the Court in Alford said:

That he would not have pleaded except for the opportunity to limit the possible penalty does not necessarily demonstrate that the plea of guilty was not the product of a free and rational choice, especially where the defendant was represented by competent counsel whose advice was that the plea would be to the defendant's advantage. ${ }^{111}$

The point of the ruling in Noia was not that the defendant's choice was not freely made or not rational, but rather that the limiting of a defendant to those particular alternatives was not constitutional, since requiring a defendant either to accept life imprisonment or to assert his constitutional rights at the risk of death violates due process. ${ }^{112}$ This

inherent in a system which permits a sentence differential based on whether the accused pleads or is tried.

107372 U.S. at 440 .

108 Alford stated that he was pleading because he was told that there was strong circumstantial evidence against him, and he would be gassed if convicted. Parker, like Noia, had given a confession, and Brady was told that a co-defendant had agreed to testify against him. Brady involved a kidnapping and Parker a rape, both crimes that arouse strong emotion and might lead a jury to recommend the death penalty. Noia gave other reasons for not appealing, see note 89 supra, and since the confession was the "sole" evidence against him, Noia would not have had much reason to fear that if he succeeded in having the confession declared inadmissable on appeal he would be retried and sentenced to death.

109 Three members of the Court concurred in Brady on the ground that his plea did not appear to have been motivated by fear of the death penalty, see note 99 supra, and dissented in Parker, urging remand for a hearing to determine that question. 397 U.S. at 814 .

110400 U.S. at 31.

111 Id.

112 Although the Court in Fay v. Noia did not refer to a particular constitutional provision in this part of the opinion, the due process clause, defined either in terms of fundamental concepts of justice or as incorporating the Bill of Rights, seems apposite. 
was also the reason for the Court's decision in Jackson. ${ }^{113}$ The death penalty provision was invalid because its effect was to require the accused to choose between a trial by jury or avoiding the risk of the death penalty, a choice which the Court held constitutionally impermissible. ${ }^{114}$ The Alford Court's suggestion that the defendant was protected since he was represented by counsel, misses the point: as long as the defendant must choose between forfeiting his legal rights or risking the death penalty, there is very little counsel can do to assist him. ${ }^{115}$ Moreover, Noia and Jackson were also represented by counsel. Thus, the argument that the defendants were represented by counsel does not distinguish Brady, Parker and Alford from Noia and Jackson.

While the Court might have invalidated the pleas in all of these cases on the broader principle that assertion of constitutional rights may not be penalized (and, indeed, Noia and Jackson can be read as applications of that principle), the Court could also have decided Brady, Parker and $A$ lford on the narrower principle that a guilty plea entered in fear of capital punishment is invalid. This would not have vitiated the plea bargaining process as a whole, but would only have eliminated prosecutorial reliance on fear of the death penalty in order to induce guilty pleas. The death penalty is and has been treated by the Court as sui generis. In Noia the Court emphasized that the "grisly choice" involved death. In Corbitt $v$. New Jersey, ${ }^{116}$ the Court distinguished Jackson on the ground that the statutory provision invalidated in Jackson involved the death penalty. Justice White, writing for the majority, stated, "[ $t]$ he principal difference is that the pressures to forgo trial and to plead to the charge in this case are not what they were in Jackson. First, the death penalty, which is 'unique in its severity and irrevocability,' is not involved here." 117 Apparently determined not to weaken the plea bargaining process even to the limited extent that a narrowly construed application of Noia and Jackson would have entailed, the Court declined to apply to the plea bargaining process the principle which it applied to non-plea bargaining cases, namely, that the relinquishment of a right induced by fear of the death penalty does not constitute a valid waiver.

113390 U.S. 570,572 (1968).

114 Together Brady and Jackson give rise to an anomalous result: while the death penalty provision of the statute is invalid because it might induce someone to waive the right to trial and plead guilty rather than risk the death penalty, if the accused succumbs to the threat and pleads guilty, the plea is valid. See Parker v. North Carolina, 397 U.S. at 807-08 (Brennan, J., dissenting).

115 For a discussion of this point, see notes $167-68$ \& accompanying text infra.

116439 U.S. 212 (1978).

117 Id. at 217. See also Beck v. Alabama, 447 U.S. 625 (1980). 


\section{(3) Admissions of Guilt Induced by Illegally Obtained Evidence: Richardson and Harrison}

The fourth amendment provision against unreasonable searches and seizures and the fifth amendment privilege against self-incrimination have been interpreted to require exclusion of evidence and "fruits" of evidence obtained in violation of these rights. ${ }^{118}$ In Harrison $v$. United States 119 the Court applied these principles to a defendant's trial testimony that was given after the prosecutor introduced into evidence confessions that were later held to have been illegally obtained. Holding that the testimony constituted "fruits" and, therefore, could not be used against the defendant at a subsequent trial, the Court stated, "the essence of a provision forbidding the acquisition of evidence in a certain way is that not merely evidence so acquired shall not be used before the Court but that it shall not be used at all." ${ }^{120}$ It rejected the reasoning of the court of appeals that the prior testimony could be used because the defendant had "made a conscious tactical decision to seek acquittal by taking the stand after [his] in-custody statements had been let in. . . ."121 The Supreme Court said, "[t]he question is not whether the petitioner made a knowing decision to testify, but why. If he did so in order to overcome the impact of confessions illegally obtained . . . his testimony was tainted by the same illegality that rendered the confessions themselves inadmissible." 122

In McMann v. Richardson, ${ }^{123}$ the Court reversed an en banc decision and two panel decisions of the Court of Appeals for the Second Circuit that applied the rationale of Harrison to guilty pleas. Justice White, writing for the majority stated, " $[t]$ he core of the Court of Appeals' holding is the proposition that . . . if there would have been no plea had there been no confession - the plea is vulnerable. . . . We are unable to agree. . . ."124 Arguing that the defendant's decision to plead is a tactical decision based on an assessment that the confession is admissible-the position taken by the court of appeals and rejected by the Supreme Court in Harrison-White concluded that the petition for relief "is at most a claim that the admissibility of his confession was mistakenly assessed." 125

118 See, e.g., Wong Sun v. United States, 371 U.S. 471 (1963); Nardone v. United States, 308 U.S. 338 (1939); Silverthorne Lumber Co. v. United States, 251 U.S. 385 (1920).

119392 U.S. 219 (1968).

$120 \mathrm{ld}$. at 222 (citation omitted).

$121 \mathrm{Id}$. at 223 (citation omitted).

122 Id.

123397 U.S. 759 (1970). See also Parker v. North Carolina, 397 U.S. 790, 796-98 (1970).

124397 U.S. at 766.

125 Id. at 769 . 
The concept of "fruit" is complex and elusive, as Justice White stated in Harrison. ${ }^{126}$ It may be argued that in view of the intervening tactical decisions by counsel and defendant, the connection between the confession and the plea had become so attenuated that the plea was not the "fruit" of the confession, that the confession was only "but for" causation. ${ }^{127}$ However, such an argument would apply equally to Harrison. The decision to testify in Harrison and the decision to plead in McMann were both tactical decisions; both were reasonable only if counsel believed that the confession might be ruled admissible by the appellate court, as it had been by the trial court; in both instances counsel was mistaken. Analytically, the two are indistinguishable; if the testimony is "fruit" the plea is "fruit" as well. Indeed Justice White argued this in Harrison. ${ }^{128}$ Thus, the case is another example of the disparate interpretation given to the same constitutional principle when plea bargaining is involved.

\section{(4) Indictment by an Improperly Constituted Grand Jury: Tollett v. Henderson}

Although the purpose of a grand jury indictment is to protect a person from being subjected to a trial where the evidence doesn't warrant it, ${ }^{129}$ the Court has repeatedly held that a claim of racial discrimination in the selection of the grand jury may be raised after the defendant has already been convicted by a petty jury. ${ }^{130}$ The Court has considered such claims both on direct review ${ }^{131}$ and on petition for habeas corpus. ${ }^{132}$ Since a grand jury need only find that the evidence is sufficient to establish probable cause for believing that the accused committed the offense and, in the case of a defendant who has been tried and convicted, a petty jury had already found that the evidence was sufficient to establish guilt beyond a reasonable doubt, reversal clearly does not serve to protect the accused from being subjected to trial where the evidence does not warrant it. Rather, it serves another purpose: that of vindicating the public policy against racial discrimination in the selection of grand juries. ${ }^{133}$ This purpose would, of course, be equally

126392 U.S. at 230.

127 See Wong Sun v. United States, 371 U.S. at $486,491$.

128392 U.S. at 234 ("an inadmissible confession preceding a plea of guilty would taint the plea.").

129 See, e.g., Y. Kamisar, W. La Fave \& J. Israel, Modern Criminal Procedure 712 (5th ed. 1980) [hereinafter cited as KAMISAR].

130 See, e.g., Peters v. Kiff, 407 U.S. 493 (1972); Alexander v. Louisiana, 405 U.S. 625 (1972); Cassell v. Texas, 339 U.S. 282 (1950).

131 See Alexander v. Louisiana, 405 U.S. 625; Cassell v. Texas, 339 U.S. 282.

132 See Peters v. Kiff, 407 U.S. 493.

133 See, e.g., Rose v. Mitchell, 443 U.S. 545 (1979); Smith v. Texas, 311 U.S. 128 (1940). 
served by permitting defendants to challenge an indictment returned by an unconstitutionally constituted grand jury where the conviction is based on a guilty plea. Nevertheless, the Supreme Court held in Tollett v. Henderson ${ }^{134}$ that if the conviction was based on a guilty plea the indictment could not be challenged thereafter on the ground of racial discrimination in the selection of a grand jury.

Tollett is consistent with a decision of the same term interpreting the Federal Rules of Criminal Procedure to bar collateral consideration of a claim to quash the indictment, ${ }^{135}$ and with the Court's decisions narrowing the scope of federal postconviction relief. ${ }^{136}$ However, the decision in Tollett cannot be explained as another instance of the Court's narrowing of collateral review. The Court has, subsequent to its decision in Tollett, emphatically rejected the suggestion that a claim of racial discrimination in the selection of the grand jury is not cognizable on habeas corpus. ${ }^{137}$ It stated:

discrimination on account of race in the administration of justice strikes at the core concerns of the Fourteenth Amendment and at fundamental values of our society and our legal system. Where discrimination that is "at war with our basic concepts of a democratic society and a representative government" . . . infects the legal system, the strong interest in making available federal habeas corpus relief outweighs the costs associated with such relief. ${ }^{138}$

Thus, this is a further example of disparate application of constitutional principles where the plea bargaining process is involved. ${ }^{139}$

\section{B. THE COURT'S ARGUMENTS FOR SUSTAINING PLEAS INDUCED BY THREATS AND PROMISES AND THE IMPOSITION OF HARSHER PENALTIES ON THOSE WHO REFUSE TO PLEAD}

The arguments given by the Court for sanctioning the plea bargaining process, already discussed to some extent in the context of specific cases, are that the accused (1) made a voluntary choice; (2) was represented by counsel; and (3) is clearly guilty.

134411 U.S. 258 (1973).

135 Davis v. United States, 411 U.S. 233 (1973).

136 See, e.g., Castaneda v. Partida, 430 U.S. 482, 507 (1977) (Powell, J., dissenting); Stone v. Powell, 428 U.S. 465 (1976) (limiting collateral relief to claims involving the validity of the guilt-determining process).

137 Rose v. Mitchell, 443 U.S. 545.

138 Id. at 564 (citation omitted).

139 One commentator suggested that the passage of 25 years between the indictment and the petition for habeas corpus in Tollett might justify the result. See Alschuler, The Supreme Court, The Defense Attorney, and The Guilty Plea, 47 U. Colo. L. REv. 1, 30 (1975). There is, however, no necessary relationship between the fact that the claim was raised many years after the event and the fact that the petitioner had pleaded guilty, which was the stated basis for the decision. 


\section{(1) Voluntary Choice}

In rejecting challenges to the plea bargaining process, the Court has repeatedly emphasized that the accused had a free choice, that his decision was voluntary. ${ }^{140}$ It is true that one who enters a guilty plea to avoid the risk of the death penalty, life imprisonment, or a long prison term and one who refuses to plead guilty and is subjected to a longer prison term has a choice in some sense of the word. However, one who is induced to confess by threats or promises, ${ }^{141}$ one who foregoes an appeal because he fears that reconviction may result in the death penalty, ${ }^{142}$ and one who pursues his right to an appeal ${ }^{143}$ or to a trial de novo ${ }^{144}$ under a law that permits retrial for a greater offense or imposition of a longer sentence following a new conviction, similarly has a choice. Nevertheless, the Court has held that use of the confession, forfeiture of the appeal, imposition of a longer sentence, and retrial for a greater offense under these circumstances contravene the constitution.

In some sense, every act other than a reflex action can be said to be voluntary. ${ }^{145}$ Where, however, the voluntariness of an act is relevant to a determination of whether one has been accorded rights guaranteed by the constitution, it is not sufficient that the choice be voluntary in some broad sense of the word. The question of voluntariness must be determined in accordance with constitutional criteria developed by the Court. The Court has declared such criteria in numerous cases, many involving the voluntariness of a confession under the fifth amendment privilege against self-incrimination and the fourteenth amendment due process clause. ${ }^{146}$ While these criteria have differed over the years, ${ }^{147}$ it

140 See Bordenkircher v. Hayes, 434 U.S. at 363-64; Santobello v. New York, 404 U.S. at 261-63; North Carolina v. Alford, 400 U.S. at 37-38; Brady v. United States, 397 U.S. at 748; Parker v. North Carolina, 397 U.S. at 794-96.

141 See, e.g., Spano v. New York, 360 U.S. 315 (1959); Bram v. United States, 168 U.S. 532 (1897). See also Ashcraft v. Tennessee, 322 U.S. 143 (1944) (Jackson, J., dissenting).

142 See Fay v. Noia, 372 U.S. 391.

143 See North Carolina v. Pearce, 395 U.S. 711.

144 See Blackledge v. Perry, 417 U.S. 21.

145 See Culombe v. Connecticut, 367 U.S. 568, 604-05 (1961) (separate opinion of Frankfurter, J.). Cf. MODEL PENAL CODE § 2.01(2) (1962) (providing that for purposes of criminal responsibility the following are not voluntary: (a) a reflex or convulsion; (b) a bodily movement during unconsciousness or sleep; (c) conduct during hypnosis or resulting from hypnotic suggestion; (d) a bodily movement that otherwise is not a product of the effort or determination of the actor, either conscious or habitual); O.W. Holmes, The Common LAW 91 (1881) ("An act is always a voluntary muscular contraction and nothing else.").

146 See, e.g., Culombe v. Connecticut, 367 U.S. 568 (1961); Watts v. Indiana, 338 U.S. 49 (1949); Bram v. United States, 168 U.S. 532 (1897). See also cases cited in note 147 infra.

147 The criteria for holding a confession involuntary and thereby inadmissible in state proceedings have been broadened over the years from physical brutality, Brown v. Mississippi, 297 U.S. 278 (1936), to extensive questioning, Ashcraft v. Tennessee, 322 U.S. 143 (1944), to psychological inducement, Spano v. New York, 360 U.S. 315 (1959), to failure to advise an accused interrogated in a custodial setting of his right to counsel and to remain silent, Mi- 
is clear that a plea induced by fear of death or a harsh penalty or by a promise of leniency is not "voluntary" under presently applicable standards for determining voluntariness of confessions. ${ }^{148}$ This argument has been well made in scholarly writings ${ }^{149}$ and judicial decisions ${ }^{150}$ and need not be repeated here.

Although the Court has refused to apply the criteria for determining voluntariness of confessions to guilty pleas, ${ }^{151}$ it has neither explained why those criteria should not apply, notwithstanding that guilty pleas and confessions are both governed by the fifth amendment privilege against self-incrimination, ${ }^{152}$ nor specified the criteria to be applied to determine voluntariness of pleas. ${ }^{153}$ Rather, it has argued that since

randa v. Arizona, 384 U.S. 436 (1966). See generally KAMISAR, supra note 129, at 553-59, and authorities cited therein. The Court had long ago held that in a federal proceeding a confession extracted "by any direct or implied promises, however slight" is involuntary. Bram v. United States, 168 U.S. 532, 542-43 (1897).

148 See 3 WigmORE, Evidence $\S \S 834-36$ (2d ed. 1923); Alschuler, supra note 4, at 218; Alschuler, supra note 139, at 51 fols. Cf. Alschuler, The Defense Attomey's Role in Plea Bargaining, 84 YALE L.J. 1179, 1212 (1975) (pleas induced by threats to prosecute friend or relative held voluntary, whereas confessions so induced held involuntary). Waiver induced by fear of imprisonment is also held "involuntary" in other contexts. See, e.g., Boyd v. Adams, 513 F.2d 83 (7th Cir. 1975), holding that a release given in exchange for dismissal of charges of disorderly conduct, prompted by fear of imprisonment, was involuntary and did not bar later action against police.

149 See McCormick, Evidence $\S \S 147-50$ (2d ed. 1972); 3 Wigmore, Evidence $§ \S 834-$ 36 (2d ed. 1923); Alschuler, The Defense Attorney's Role, supra note 148.

150 See Shelton v. United States, 242 F.2d 101 (5th Cir. 1957), rev'd en banc, 246 F.2d 571, rev'd on confession of error by the Solicitor General, 356 U.S. 26 (1958); People v. Byrd, 12 Mich. App. 186, 203 fols., 162 N.W.2d 777, 785 fols. (1968) (Levin, J., concurring).

151 Compare Santobello v. New York, 404 U.S. 257 (a guilty plea induced by a promise is valid as long as the promise is kept) with Bram v. United States, 168 U.S. 532 (1897) and Boyd v. Adams, 513 F.2d 83.

152 Actually, application of the privilege to guilty pleas is on firmer ground than its application to extra-judicial admissions. The fifth amendment provides that no one shall be compelled to be a witness against himself in any criminal case. It has been argued that it should not be applied to statements obtained by the police at the investigatory stage, since there is no "criminal case" at that time. See Miranda v. Arizona, 384 U.S. 436, 510 (Harlan, J., dissenting) ("The Court's opinion in my view reveals no adequate basis for extending the Fifth Amendment privilege against self-incrimination to the police station."). Its application to guilty pleas, entered in court, after indictment, cannot, of course , be questioned on that basis.

153 In Brady v. United States, 397 U.S. 742, 755, the Court quoted Judge Tuttle's statement in Shelion:

[A] plea of guilty entered by one fully aware of the direct consequences, including the actual value of any commitments made to him by the court, prosecutor, or his own counsel, must stand unless induced by threats (or promises to discontinue improper harassment), misrepresentation (including unfulfilled or unfulfillable promises), or perhaps by promises that are by their nature improper as having no proper relationship to the prosecutor's business (e.g., bribes).

Judge Tuttle justified application of these criteria to guilty pleas rather than the criteria used to determine voluntariness of confessions on the ground that application of the latter to guilty pleas "would considerably impede the administration of justice . . . " Shelton v. United States, 242 F.2d at 115. Justice White argued that the Court's holding in Brady, that a plea induced by a promise of leniency was voluntary, was not inconsistent with the Court's hold- 
guilty pleas are induced by fear of a greater penalty and by promises of a lenient sentence, pleas induced by such methods must be voluntary. Thus, the Court stated in Bordenkircher,

acceptance of the basic legitimacy of plea bargaining necessarily implies rejection of any notion that a guilty plea is involuntary in a constitutional sense simply because it is the end result of the bargaining process. By hypothesis, the plea may have been induced by promises of a recommendation of a lenient sentence or a reduction of charges, and thus by fear of the possibility of a greater penalty upon conviction after a trial. ${ }^{154}$

The problem with this approach is that it "accept[s] the basic legitimacy of plea bargaining" and concludes that pleas so induced must be voluntary, instead of starting with criteria for defining voluntariness and then applying these criteria in order to determine whether a particular plea bargain, or plea bargaining generally, is voluntary.

The Court also relies on the voluntariness arguments to reject challenges to the plea bargaining process based on the contention that the imposition of different sentences depending on whether the accused pleads or insists on a trial, violates the principle that assertion of legal rights may not be penalized. However, as has already been discussed, under traditional analysis voluntariness and unconstitutional penalties are distinct principles, neither of which may be violated if a conviction is to stand, whereas, under the majority's analysis in Garrity, requiring one to waive a constitutional right in order to avoid a penalty renders the choice involuntary by definition. ${ }^{155}$ Thus, the argument that the plea bargaining process does not contravene the principle that the assertion of legal rights may not be penalized because the choice was voluntary is untenable under both analyses.

\section{(2) Presence of Counsel}

Another argument found repeatedly in the cases sustaining pleas induced by fear of harsh penalties or promises of lenient ones is that the

ing in Bram v. United States, 168 U.S. 522, that "even a mild promise of leniency was deemed sufficient to bar the confession." 397 U.S. at 754 . He stated, "[b]ut Bram and its progeny did not hold that the possibly coercive impact of a promise of leniency could not be dissipated by the presence and advice of counsel, any more than Miranda $v$. Arizona held that the possibly coercive atmosphere of the police station could not be counteracted by the presence of counsel or other safeguards." 397 U.S. at 754 (citations omitted). The two are not analogous, however. In the situation to which Miranda is addressed the coercion is external and can be dissipated by the presence of counsel, whereas in plea bargaining, "[w]here the choice is 'between the rock and the whirlpool,' duress is inherent in deciding to 'waive' one or the other," to borrow Justice Douglas' language in Garrity v. New Jersey, 385 U.S. 493, 498 (1967), and cannot be dissipated by the presence of counsel. See also notes 164,167 infra.

154 Bordenkircher v. Hayes, 434 U.S. at 363.

155 See text accompanying notes 46-57 supra. See also the language of Justice Brennan quoted in note 51 supra. 
accused was represented by counsel. ${ }^{156}$ While presence of counsel is relevant to the constitutionality of a conviction in a number of ways, it is difficult to discern what bearing the presence of counsel has on whether use of threats and promises to induce guilty pleas comports with constitutional requirements. The presence of counsel may be a necessary condition for a conviction to stand, but it is obviously not a sufficient condition.

The sixth amendment establishes an accused's right to representation by retained counsel at all criminal trials. ${ }^{157}$ In view of the complexity of the criminal process and the need for counsel to ensure a fair trial, the Court has also held that an indigent accused is entitled to appointment of counsel in all felony trials, ${ }^{158}$ misdemeanors involving the possibility of imprisonment, ${ }^{159}$ and at certain other stages of the process. ${ }^{160}$ Failure to provide counsel in these situations may vitiate the conviction. ${ }^{161}$ Presence of counsel may also be relevant if the accused fails to assert a right or to object to a violation of his rights at any stage of the process. It may be argued that since he was represented by an attorney who knew or should have known of the right, the failure to assert the right or to object to its violation was a deliberate tactical decision binding on the accused. ${ }^{162}$

The Court has also ruled that either counsel must be present or the accused must have an opportunity to consult with counsel at certain investigatory stages and has enforced this rule by providing for the exclusion of evidence obtained in violation of this requirement. ${ }^{163}$ The requirement of counsel at certain stages of the evidence gathering process and the exclusion of evidence obtained in violation of that requirement is designed to ensure that methods used by the police to obtain evidence meet constitutional standards. ${ }^{164}$ But counsel's presence does not authorize the use of methods that would otherwise be improper. For

156 See, e.g., Bordenkircher v. Hayes, 434 U.S. 357, 363; Brady v. United States, 397 U.S. 742, 750, 754; Parker v. North Carolina, 397 U.S. 790, 796.

157 Earlier English practice did not permit the accused to have counsel in certain felony trials. See Powell v. Alabama, 287 U.S. 45, 60 (1932).

158 See Gideon v. Wainwright, 372 U.S. 335 (1963).

159 See Argersinger v. Hamlin, 407 U.S. 25 (1972).

160 See, e.g., Coleman v. Alabama, 399 U.S. 1 (1970) (holding the accused entitled to counsel at the preliminary hearing).

161 See cases cited in notes $158-60$ supra.

162 See, e.g., Estelle v. Williams, 425 U.S. 501 (1976); Henry v. Mississippi, 379 U.S. 443 (1965). The extent to which silence by the defendant or his attorney may be deemed a waiver by the defendant is a complex question, outside the scope of this article.

163 See, e.g., United States v. Wade, 388 U.S. 218 (1967) (line-up identification); Miranda v. Arizona, 384 U.S. 436 (custodial interrogation).

164 In custodial interrogation the presence of counsel may also serve to dispel a coercive atmosphere. In plea bargaining, the attorney's role is just the opposite. "Rather than dispel the coercive impact of a promise of leniency, the attorney must make the defendant realize 
example, a defendant is entitled to counsel at a lineup identification and if a post-indictment lineup is conducted without counsel, the out-ofcourt identification is not admissible. ${ }^{165}$ However, it has never been suggested that the presence of counsel would render a highly suggestive lineup, conducted over counsel's protests, lawful. Similarly, a person in custody must be advised of his right to remain silent and to consult counsel. If the accused indicates a desire to consult counsel, he must be given an opportunity to do so prior to police interrogation; failure to do so renders any statement he makes inadmissible. ${ }^{166}$ Yet, surely no one would argue that a confession induced by beatings, threats, or promises was lawful if the accused first consulted an attorney or if these events occurred in the presence of an attorney. It is equally illogical to argue that a guilty plea induced by fear of death or of a harsh sentence, or the imposition of a longer sentence than was otherwise deemed warranted on one who refused to enter a guilty plea, comport with due process requirements because the accused was represented by counsel. Representation by an attorney is meaningful only if the accused has rights about which he can be advised or which the attorney can invoke on the accused's behalf. ${ }^{167}$ Representation by an attorney has no bearing on whether certain government conduct should be proscribed or permitted, and it does not justify conduct that is otherwise constitutionally proscribed. ${ }^{168}$

\section{(3) Defendant's Guilt}

A third argument made by the Court in defense of plea bargaining is that those convicted are clearly guilty. ${ }^{169}$ Although in determining

with full clarity the coercive power of the alternatives that he faces." Alschuler, supra note 139 , at 58 .

165 United States v. Wade, 388 U.S. 218.

166 Miranda v. Arizona, 384 U.S. 436.

167 The skills of an attorney are helpful insofar as the proceedings involve legal problems about which he has some expertise and with which a layman is not expected to be familiar. See Gideon v. Wainwright, 372 U.S. 335. Where, however, the accused must choose between giving up his "day in court" and risking the death penalty the skills of an attorney have no special relevance (other than making an educated guess as to the likelihood of defendant's being convicted on the basis of whatever evidence he knows the prosecutor to have).

Interpreting the Court's reference to the fact that the accused was represented by counsel as bearing on the voluntariness of the plea, Alschuler comments, "[ $t]$ he presence of counsel has little relevance to the question of voluntariness. A guilty plea entered at gunpoint is no less involuntary because an attorney is present to explain how the gun works." Alschuler, supra note 139, at 55 .

168 Of course, each of the defendants in Fay v. Noia, Pearce v. North Carolina, and Blackledge $v$. Perny had counsel. That did not prevent the Court from holding the procedure involved unconstitutional. See also authorities cited in Alschuler, supra note 139, at 55 n.179.

169 See, e.g., Bordenkircher v. Hayes, 434 U.S. 357, 363; Brady v. United States, 397 U.S. $742,748,758$. 
the scope to be given to a particular right and the remedies to be provided for its violation, courts may consider the effect on the validity of the guilt determining process, ${ }^{170}$ the application of constitutional rights does not depend on the guilt or innocence of the accused. Some of the constitutional provisions that apply to the criminal justice process serve purposes other than minimizing the possibility of error in the adjudicatory process. ${ }^{171}$ Even those directed primarily at ensuring the validity of the guilt determining process may not be denied to an accused because his guilt is clear. ${ }^{172}$ The Supreme Court has long held that certain governmental conduct is constitutionally unacceptable regardless of the defendant's guilt. ${ }^{173}$ While the Burger Court has emphasized the importance of rights that affect the reliability of the guilt determining process, it has also reaffirmed and extended the protection provided by constitutional provisions that do not affect the accuracy of that process $^{174}$ and it has reversed convictions based on improper governmental conduct even though the defendant's guilt was clear. ${ }^{175}$

Turning to the merits of the argument, it does not follow that because the accused has pleaded guilty, he is in fact guilty. The Court's decisions suggest that a defendant who pleads guilty is clearly guilty since a) he admits guilt and b) the trial court is required to satisfy itself that he is guilty before accepting the plea. This reasoning is fallacious in several respects. First, not everyone pleading guilty admits guilt. In $\mathrm{Al}$ ford,${ }^{176}$ the Court specifically held that one may enter a valid guilty plea while maintaining his innocence. Secondly, even an admission of guilt does not provide assurance of guilt. ${ }^{177}$ Most defendants admit guilt because they have been instructed to do so in order to assure the court's

170 See, e.g., Stone v. Powell, 428 U.S. 465; see also Friendly, Is Innocence Relevant? Collateral Attack on Criminal Judgments, 38 U. CHI. L. REV. 142 (1970).

171 E.g., the fourth amendment requirement of a warrant.

172 See, e.g., Brewer v. Williams, 430 U.S. 387 (1977), where the accused was clearly guilty but the conviction was reversed because he had been denied the right to counsel.

173 See, e.g., Rochin v. California, 342 U.S. 165, 172 (1952) ("It has long ceased to be true that due process of law is heedless of the means by which otherwise relevant and credible evidence is obtained." Watts v. Indiana, 338 U.S. 49 (1949).

174 See, e.g., Payton v. New York, 445 U.S. 573 (1980), holding for the first time that police must have a warrant to enter a suspect's home to make a routine felony arrest.

175 See, e.g., Brewer v. Williams, 430 U.S. 387; Coolidge v. New Hampshire, 403 U.S. 443 (1971).

176 See North Carolina v. Alford, 400 U.S. 25. See also ALI A Model Code OF PreArraignment Procedure § 350.4(4) (Tent. Draft No. 5, 1972), recommending that the court be authorized to accept a plea "even though the defendant does not admit that he is in fact guilty if the court finds that it is reasonable for someone in the defendant's position to plead guilty."

177 See Note, Voluntary False Confessions: A Neglected Area in Criminal Administration, 28 IND. L.J. 374 (1953). The author cites one famous murder in which there were "more than twenty false confessions," id. at $380 \mathrm{n} .26$, and another case in which several persons confessed to and were convicted of the same murder. Id. at 375-76. 
acceptance of the plea. ${ }^{178}$ Some people confess to crimes they have not committed because they have a psychological need to do so. ${ }^{179}$

In Brady the Court stated "[w]e would have serious doubts about this case if the encouragement of guilty pleas by offers of leniency substantially increased the likelihood that defendants advised by competent counsel, would falsely condemn themselves." 180 Given sufficient sentence differential, an accused may decide to plead guilty even though he is innocent. The rationality of a decision to plead guilty depends not on the accused's guilt or innocence but on the strength of the state's case ${ }^{181}$ and on the inducement offered. ${ }^{182}$ For example, a defendant charged with a capital crime who can avoid risking the death penalty, or one who is offered a sentence to time already served if he pleads guilty but faces the prospect of several more years in prison if convicted after trial, may rationally decide not to take that risk even if he is in fact innocent. ${ }^{183}$ Competent counsel may advise a defendant to plead guilty in such circumstances even though he believes his client's assertions of innocence, or, at least, is not certain of his guilt. ${ }^{184}$ The purpose of and

178 See note 193 infra. See also Enker, supra note 49, at 111.

179 That innocent persons confess to crimes they have not committed for psychological reasons is well known. See Note, supra note 177, at 378 fols., and authorities cited therein. Maimonides cited this as a reason for the rule in the Talmud "that no man is to be declared guilty on his own admission." The Code of Maimonides, Book XIV, The Book of Judges (A. Hershman trans.), in YALE JudAicA SER. 53 (1949). For further discussion of this Talmudic rule and comparison with the fifth amendment privilege, see Lamm, The 5th Amendment and Its Equivalent in Jewish Law, 17 Decalogue J. 1, 10-11 (1967).

180 Brady v. United States, 397 U.S. 742, 758.

181 The state may have a strong case against the defendant, based on circumstantial evidence or erroneous identification, even if he is innocent. See P. WALl, Eyewitness IDENTIFICation in Criminal Cases (1965); Buckhout, Eyewitness Testimony, Sci. AM., Dec. 1974, at 23. See also Watkins v. Sowders, 449 U.S. 341 (1981) and authorities cited therein. Justice Brennan speaks of "inherently suspect qualities of eyewitness identification evidence" and notes that "the annals of criminal law are rife with instances of misidentification." Id. at 350 51 (Brennan, J., dissenting).

182 Even when the case against the defendant is weak, the offer may be such as to make it rational for the accused to plead rather than to go to trial. Research has shown that the weaker the prosecutor's case, the greater the incentive offered for a plea and that "the greatest pressures to plead guilty are brought to bear on defendants who may be innocent." Alschuler, supra note 79, at 60. See generally id. at 58-64; Alschuler, The Defense Attomey's Role in Plea Bargaining, supra note 148, at 1203.

183 For a discussion of such situations see Alschuler, supra note 79, at 61 . One commentator has analogized the plea bargaining situation facing the accused to the situation confronting the victim of a gunman demanding his money. In both situations a reasonable person might conclude, "I can't take the chance." See Brunk, The Problem of Voluntariness and Coercion in the Negotiated Plea, 13 LAw \& Soc. Rev. 527, 529 (1979).

184 See Alschuler, supra note 79, at 61 ; Alschuler, supra note 139 , at 9 . This situation poses a moral dilemma for the attorney who believes that there is nevertheless a substantial likelihood that the accused will be convicted: should he advise him to plead guilty and avoid the risk of more severe punishment, or should he urge him to go to trial, in the hope that a weakness in the prosecution's evidence will be revealed, or that new evidence supporting the accused's 
justification for a sentence differential is precisely that it induces defendants who would not otherwise plead guilty (or it would not be necessary to use threats or promises as an inducement) to do so.

It is, of course, impossible to know how many of those who plead guilty are innocent, or who, in the Court's words, "falsely condemn themselves." However as Enker noted, "[t]he significant question is not how many innocent people are induced to plead guilty but is there a significant likelihood that innocent people who would be (or have a fair chance of being) acquitted at trial might be induced to plead guilty?"185 Though favoring plea bargaining, Enker stressed that "at a minimum [due process] requires a fair fact finding procedure designed to find the relevant facts accurately," 186 and that "conviction by judicial admission" does not satisfy this requirement if the "admission has been induced by unfair means which might induce an innocent person to plead guilty."187 A statistical analysis of federal convictions based on trials and on guilty pleas concluded that one-third of those who plead guilty would not be convicted after trial. ${ }^{188}$ The author of the study stated, "the inducement of guilty pleas is not merely a way of shortening the criminal process. Instead, pressures to plead guilty have been used to secure convictions that could not otherwise be obtained." 189 Interviews with defense attorneys ${ }^{190}$ and prosecutors ${ }^{191}$ in nine urban jurisdictions leave little doubt that the plea bargaining process might well, to use Enker's test, "induce an innocent person to plead guilty."

Nor does the requirement that the court satisfy itself that the accused is guilty prior to accepting the plea eliminate the problem. This requirement is usually met by the court's asking the accused whether he,

innocence will be discovered, or that he will succeed in convincing the fact-finder of his client's innocence in some other way. For a description of the personal agony that this problem posed for one attorney, see Wilson, The Fifh Amendment and Guilty Plea: An Incompatible Association, 30 HASTINGS L.J. 545 n.79 (1979). Even an attorney who is confident he can establish his client's innocence may agree to a plea if the charge is serious and the offer is for a plea to a crime that carries a minimal sentence. Moreover, research has shown that attorneys put considerable pressure on clients to plead guilty for a variety of reasons, some of which are unrelated to the accused's guilt or innocence or to the likelihood of conviction. These include the attorney's desire to earn a fee quickly, a heavier caseload than the attorney can handle, fear or inability to try a case, the need to maintain a good working relationship with the prosecutor or judge, and dispostion of several cases as a package deal. See Alschuler, The Defense Attomey's Role in Plea Bargaining, supra note 148, at 1182 fols.

185 Enker, supra note 49, at 113.

$186 \mathrm{Id}$. at 116.

187 Id. (emphasis added).

188 Finkelstein, A Statistical Analysis of Guilty Plea Practices in the Federal Courts, 89 HARV. L. REV. 293, 309 (1975).

189 Id. at 309.

190 See Alschuler, The Defense Attomey's Role in Plea Bargaining, supra note 148.

191 See Alschuler, supra note 139. 
in fact, did the various acts alleged in the charge. ${ }^{192}$ Since the defendant has generally been instructed on what he must say if he wishes the court to accept the plea and implement the "bargain," his replies at this point do not provide reliable assurance of guilt. ${ }^{193}$ Even if the court requests additional evidence before accepting the plea, this is usually accomplished by the prosecutor's briefly summarizing the state's evidence or submitting the minutes of the grand jury proceedings. Such evidence, however, has not been subjected to the various rules for excluding biased or otherwise unreliable evidence, nor to the rigors of cross-examination. It may be argued that these safeguards are necessary only when the accused does not plead guilty; that if the accused pleads guilty, safeguards against erroneous conviction are not necessary, as the accused has admitted his guilt. As stated above, however, the accused's plea does not necessarily constitute a reliable admission of guilt. Futhermore, the argument is circular. It first relies on the defendant's admission of guilt to buttress a perfunctory review of the evidence and then relies on such a perfunctory review of the evidence to support the reliability of the plea. It is questionable whether combining these two procedures is sufficient to assure that innocent persons are not convicted, when either procedure, taken by itself, is clearly insufficient to do so.

The finding does not mean that a third of those who plead guilty would not be convicted after trial, one-third of those who plead guilty are innocent. Hopefully, the number of innocent persons who plead guilty is not large. However, that does not justify the plea bargaining process. If the police officers who investigate the crime and compile the evidence, the prosecutor who decides whether to present the evidence to the grand jury, and the grand jury which decides whether the evidence is sufficient to bring the accused to trial, are not incompetent or corrupt, then the number of innocent persons charged will also be small. The elaborate system for adjudicating guilt developed in Anglo-American jurisprudence, and the systems for adjudicating guilt developed by other countries that value individual liberty, were all created to prevent conviction of those few who are erroneously accused. The danger in using threats and promises to induce guilty pleas goes beyond the number of innocent persons erroneously convicted. The real danger is that a system which indiscriminately pressures both the guilty and the innocent

192 See MiLler, supra note 5, at xlvi ("In three fourths of the jurisdictions visited, judges determine factual basis and accuracy of the plea by simply asking the defendant if he committed the offense charged.") See also People v. Byrd, 12 Mich. App. 186, 162 N.W.2d 777, 790 n.28 (1968) (Levin, J., concurring), and text accompanying note 150 supra.

193 Alschuler found that "attorneys freely admitted that they advised their clients to lie, explaining to the clients that the court would not accept their pleas unless they did so." Alschuler, The Defense Attomey's Role in Plea Bargaining, supra note 148, at 1306. 
to plead guilty is substituted for a system whose primary aim is to ensure the reliability of the fact finding process.

Finally, a system that relies on threats and promises to induce guilty pleas necessitates the imposition of harsher penalties on those who reject the inducement. ${ }^{194}$ Even if it were clear that all of those who plead guilt are, in fact, guilty and that this would justify resorting to practices otherwise held to be unconstitutional to ensure their conviction, the argument that those who plead guilty are guilty, like the arguments that the defendant's choice was voluntary and that the defendant was represented by counsel, offers no justification for penalizing those who insist on their constitutional right to trial.

\section{The Need for Plea Bargaining}

\section{A. CASE PRESSURE}

It is evident from the preceding discussion that the reasons given by the Supreme Court for sustaining the plea bargaining process fail to distinguish the plea bargaining cases from other decisions involving the same constitutional principles or to justify the results. The more probable explanation for the Court's position on plea bargaining, adverted to in some of the decisions, ${ }^{195}$ made very clear by Chief Justice Burger in his extra-judicial statements, ${ }^{196}$ and widely accepted as a justification for sanctioning the process ${ }^{197}$ (even by those opposed to it ${ }^{198}$ ), is the belief that if the Court prohibited the use of such practices to induce guilty pleas, then the already over-burdened system for the administration of criminal justice would be unable to function. Thus, the Court stated in Santobello v. New York, "[i]f every criminal charge were subjected to a

194 The need to gain the acquiescence of most accused persons leads officials to place a heavy price in the form of enhanced severity - authorized by statute - on those who insist on a formal trial but who are found guilty. An example occasionally must be made of the uncooperative defendant who contests his case unsuccessfully.

A. ROSETT \& D. CRESSEY, supra note 10, at 156 . For a discussion and rejection of the suggestion that a distinction may be drawn between imposing a harsher penalty on those who demand a trial and according leniency to those who plead, and of the view that while the former is unethical and/or unconstitutional the latter is not, see text accompanying notes 70 73 supra.

195 See, e.g., Santobello v. New York, 404 U.S. 257, 260.

196 See Burger, The State of the Judiciary-1970, 56 A.B.A.J. 929, 931 (1970).

197 See generally MILLER, supra note 5, at 23:

By far, the most common rationale favoring plea bargaining was the need to move the caseload. In larger jurisdictions statistics were offered to indicate the tremendous number of cases filed for disposition each month. Some judges opposed to plea bargaining grudgingly admitted the necessity of living with it. We were told repeatedly that without plea bargaining the system would break down and justice would collapse.

Id. at 232. See also Alschuler, supra note 79, at 50-51; Baldwin \& McConville, supra note 79, at 287 ("The operation of the principle can scarcely be squared with justice: it exists primarily because of administrative expediency.").

198 See Miller, supra note 5, at 232. 
full-scale trial, the States and the Federal Government would need to multiply by many times the number of judges and court facilities." 199 Similarly, in an address to the American Bar Association Chief Justice Burger stated:

The consequence of what might seem on its face a small percentage change in the rate of guilty pleas can be tremendous. A reduction from $90 \%$ to $80 \%$ in guilty pleas requires the assignment of twice the judicial manpower and facilities-judges, court reporters, bailiffs, clerks, jurors and courtrooms. A reduction to $70 \%$ trebles this demand. 200

Underlying these arguments are two assumptions: a) that without sentencing leverage to induce guilty pleas the number of pleas would decrease and the number of trials would increase significantly; and b) that the increase in trials would require substantially greater prosecutorial and judicial resources than is currently required. Both are factual assumptions that have not been validated empirically.

There has been no empirical study to determine what percentage of persons charged would go to trial if the use of threats and promises to induce pleas were abolished. While it is true that a defendant would have little to lose by going to trial, ${ }^{201}$ the typical criminal defendant ${ }^{202}$ would also have little to gain ${ }^{203}$ by proceeding to trial where the state's evidence is clearly sufficient to establish guilt beyond a reasonable doubt. ${ }^{204}$ Thus, in many cases defendants would have no reason to de-

199404 U.S. 257, 260 (1971). See also Blackledge v. Allison, 431 U.S. 63. (The "guilty plea and the often concomitant plea bargain are important components of this country's criminal justice system.") Id. at 71 .

200 Burger, supra note 196, at 931.

201 A non-indigent defendant would incur trial expenses such as attorney's fees and court reporter fees, which may be considerable.

202 That is, one charged with crimes such as murder, robbery or burglary. The situation is, of course, different in cases that involve political protest (e.g., burning draft cards) or conduct which a segment of society believes should not be criminal (e.g., using marijuana, sexual acts between consenting adults); in those cases a defendant may have reason to demand a trial notwithstanding that the evidence is incontrovertible. In political cases the defendant may want to use the trial to publicize his views. In cases involving conduct which a substantial part of society does not consider wrong, a jury might acquit even if the evidence established beyond any doubt that the defendant engaged in the proscribed conduct.

203 While the possibility that a jury would refuse to convict even where the evidence clearly established guilt beyond a reasonable doubt cannot be ruled out completely, the probability, in a properly functioning system, would be de minimus.

204 If the evidence is clearly insufficient to establish guilt beyond a reasonable doubt, use of the sentencing differential to induce a guilty plea raises serious moral questions. Since the evidence of guilt is by hypothesis insufficient to sustain a conviction, the accused (a) would either not have been convicted after a trial or, if convicted, would have been entitled to a reversal on appeal, (b) must have entered the plea only because he and his attorney were not aware of the paucity of the state's evidence and/or because he had bad advice and (c) may in fact be innocent (unless one assumes that the prosecutor is prescient and knows that the defendant is guilty notwithstanding the absence of sufficient evidence to establish guilt). While it is also possible that an accused against whom the state lacks sufficient evidence pleads 
mand a trial. ${ }^{205}$

Furthermore, even if a greater number of defendants would demand a trial, it does not follow that significantly greater resources would be needed as a result. While a trial takes more time than the entry of a guilty plea, considerable court and attorney time is lost by motions for adjournment and other pretrial maneuvers related to plea bargaining. My own impressions as an Assistant District Attorney in New York County accord with Alschuler's conclusion, based on interviews with prosecutors and defense counsel in a number of major urban jurisdictions that "[t]he guilty plea system far from conserving judicial and prosecutorial resources, has exactly the opposite effect." 206 Even those who would retain plea bargaining concede that "time and delay are used as tactics by both the prosecutor and the defense counsel" and that "[j]ustice in these cases is by no means speedy." 207

The experience of the few jurisdictions that have attempted to ban or limit plea bargaining does not support the conclusion that prohibiting the use of a sentence differential to induce guilty pleas would result in a greatly increased demand for trials, overwhelming the courts and requiring substantially greater resources to deal with criminal cases; quite the contrary. A study of plea bargaining in the United States, ${ }^{208}$ which included several jurisdictions that have attempted to limit or

guilty because he wishes to pay his debt to society, such a plea is, of course, not induced by the sentence differential.

The possibility that the defendant is innocent is not a factor where evidence clearly sufficient to establish guilt beyond a reasonable doubt exists but has been suppressed under one of the exclusionary rules. It is tempting to argue that in that situation plea bargaining should be permitted. The accused is clearly guilty and will escape punishment/restraint only because of a technicality. Upon analysis, however, it is evident that this argument reflects either disbelief in the deterrent effect of the exclusionary rule or disagreement with its underlying premise - that it is more important to deter police from violating certain rights than it is to punish/restrain criminals. To the extent that police officers who would otherwise violate individual rights would be deterred from doing so by the knowledge that the violation will not aid in the suspect's conviction - the rationale underlying the exclusionary rules-permitting a conviction by use of the evidence to induce a plea would, of course, undermine the deterrent effect.

205 That has been the experience in Alaska. Even after plea bargaining was abolished "the prevailing mode of disposition continued to be dismissal and guilty plea. . . . With or without 'insurance' or 'concessions' most defendants and counsel apparently believed that when their charges were not dismissed, pleading guilty was their best recourse." ALASKA STUDY, supra note 13, at 222-24. See also note 221 \& accompanying text infra.

206 Alschuler, supra note 79, at 58 . For a list of various "time consuming strategies" used by defense counsel, see id. at 55-56. See also Miller, supra note 5, at 239; A. ROSETT \& D. CRessey, supra note 10, at 212-22; Alschuler, The Defense Attomey's Role in Plea Bargaining, supra note 148 , at $1230-35$.

207 A. Rosett \& D. CRessey, supra note 10, at 36.

208 MiLleR, supra note 5. 
abolish plea bargaining, ${ }^{209}$ found that none of the jurisdictions experienced the dire consequences predicted. ${ }^{210}$ Noting that "[s]ome jurisdictions within a state try $100 \%-300 \%$ more cases than another jurisdiction," [sic], the authors wonder "whether these fluctuations may be accounted for by factors other than administrative necessity and case backlog." 211 They state, "[w]e draw no conclusions from the statistics presented in this chapter. But we do ask whether jurisdictions with double or triple the trial rate of other jurisdictions have a corresponding increase in costs. We question whether 'unique' jurisdictional problems alone explain the wide variances which exist." 212

In Alaska plea bargaining has been prohibited since 1975. The Attorney General issued memoranda banning both sentence and charge reduction in return for a plea of guilty. ${ }^{213}$ An evaluation of the effects of

209 El Paso, Texas; New Orleans, Louisiana; and Alaska. See Miller, supra note 5, at 9 (Table 2), 37-40.

210 For example, the study found that in New Orleans, which prohibited charge reduction in most cases, about $88 \%$ of the guilty pleas were to the original charge. See MiLler, supra note 5 , at 9 . The study does not indicate, however, what percentage of defendants pleaded guilty in New Orleans.

211 Id. at 23.

212 Id. at 24. See also United States v. Griffin, 462 F. Supp. 928 (E.D. Ark. 1978); C. Tномssen \& P. Falkowski, Plea Bargaining in Minnesota: The Final Report of the Plea Negotiation Study (1979); Berger, The Case Against Plea Bargaining, 62 A.B.A.J. 621, 622-24 (1976). The Minnesota study found that in the eleven counties surveyed, plea bargaining rates ranged from a low of 46 percent to a high of 92 percent and that this variation could not be attributed to county population or criminal caseload. The court in Griffin stated that it "has been able to handle its criminal docket expeditiously, and has not found clearcut evidence that there is any great disparity in the percentage of its criminal cases which proceed to trial, when compared to courts in other districts which do accept plea agreements," and expressed doubt that in the federal courts there is a "factual basis" for the argument that "efficient administration of the courts requir[ed] the use of plea agreements." 462 F. Supp. at 932.

213 See Alaska Study, supra note 13, at 1, 255 fols. (app. A). The Attorney General's instructions prohibited negotiation of sentences and reduction of charges as a quid pro quo for a guilty plea. They did not prohibit guilty pleas or reduction or dismissal of charges where the evidence warranted it. While it would be irrational to prohibit reduction or dismissal of charges where the evidence warrants it, this possibility can be used (a) to avoid the ban on plea bargaining by prosecutors unsympathetic to it and (b) to argue that plea bargaining still exists in Alaska, by those who believe that the system would be overwhelmed if plea bargaining were prohibited. Realizing this, the Attorney General issued further memoranda following the initial memorandum to make clear that he did not want prosecutors to "charge heavily under the assumption that you can later reduce the charge in exchange for a guilty plea," id. at 21, and that "/c]harges should be dismissed or decreased only under unusual circumstances, only then where justified by the facts in a case, and not as a quid pro quo for the entry of a plea of guilty." Id . at 22 (emphasis in original). Although attorneys expressed different views on the extent to which plea bargaining continued in this guise, $i d$. at $55-56,127$, and it may vary from city to city within Alaska, id. at 27-72, most agreed that "charge reductions were usually based on legitimate interpretation of the evidence rather than the mere desire to induce a guilty plea in order to avoid a trial." Id. at 67.

Indictments charging lesser included offenses, several offenses arising out of a unitary criminal event or transaction, forgery of several checks, and successive sales of narcotics to the 
this new ${ }^{214}$ policy by the Alaska Judicial Council, based on a four year survey of the practice in Alaska's three largest cities, ${ }^{215}$ concludes that "the institution of plea bargaining was effectively curtailed," 216 that it was not "replaced by implicit or covert forms of the same practice," 217 and that "court processes did not bog down; they accelerated." 218 The authors of the report comment, "[s]upporters and detractors of plea bargaining have both shared the assumption that, regardless of the merits of the practice, it is probably necessary to the efficient administration of justice. The findings of this study suggest that, at least in Alaska, both sides were wrong."219 Although there was some decline in guilty pleas and an increase in trials, the overall increase in trials was less than three percent. ${ }^{220}$ " $[\mathrm{M}]$ ost defendants continued to plead guilty because, whether or not they were afforded the certainty of binding prosecutorial commitments, the alternative of going to trial seemed a fruitless act."221 Moreover, notwithstanding the increase in trials, there was a substantial

same agent are cited as examples of situations in which some counts were dismissed following a guilty plea. In some of these situations-for example dismissal of counts charging lesser included offenses when the defendant pleads to the higher charge-multiple convictions would, of course, be barred by the double jeopardly clause of the fifth amendment. See Brown v. Ohio, 432 U.S. 161 (1977); Blockburger v. United States, 284 U.S. 299 (1932). See also Model Penal Code $\$ 1.07$. While separate convictions for successive sales of narcotics to one informer would not be barred by the fifth amendment or under the Model Penal Code, it is doubtful that any purpose is served by permitting the state to multiply convictions in this manner.

214 Prior thereto plea bargaining had been taken "completely for granted" in Alaska "for as long as practitioners could recall." ALASKA STUDY, supra note 13, at 1 .

$215 \mathrm{Id}$. at v. Statistical data are only given for the year preceding the ban and the year following it.

$216 \mathrm{Id}$.

$217 \mathrm{Id}$.

218 Id. See also Rubinstein \& White, Alaska's Ban on Plea Bargaining, 13 LAW \& Soc. REv. 367 (1979):

When the Attorney General first announced his decision to ban plea bargaining, panic spread through the Alaska court system. There was considerable apprehension that defendants would refuse to plead guilty, leading to an overwhelming volume of trials - the standard in terrorem predictions advanced against any proposed curtailment of plea bargaining. At the very least, a massive slowdown in the docket was anticipated. None of these dire predictions came to pass. In fact, just the opposite occurred.

Id. at 373-74.

219 Alaska Study, supra note 13, at 102-03.

220 Trials as a portion of all dispositions increased from 6.7 percent to 9.6 percent. The number of trials went from 109 to 149 , an increase of $37 \%$. Id. at 151 .

$221 \mathrm{Id}$. at 80. See also id. at 223; Rubinstein \& White, supra note 218. "[W]hen all was said and done, most defendants continued to plead guilty even if they had to walk into an open sentencing for the crimes with which they were originally charged. . . II $I$. at 380 . Other jurisdictions that have prohibited charge or sentence reduction as a quid pro quo for a plea also found that there was no substantial increase in trials as a result. See Bayley, Plea Bargaining: An Offer A Prosecutor Can Refuse, 60 JuD. 229 (1976). Commenting on the experience of Seattle, Washington, Bayley states, "Our experience confirms that of prosecutors in San Diego and Phoenix, who report no significant increase in trials with the curtailment of plea bargaining." Id. at 232 . 
decrease in disposition time. ${ }^{222}$ " $[\mathrm{C}]$ ontrary to all expectations, the curtailment of plea bargaining did not in any way tend to impede court efficiency. . . ."223

While the experience of Alaska and the other jurisdictions that have limited plea bargaining does not conclusively refute the argument that if plea bargaining were abolished the system would be overwhelmed, ${ }^{24}$ it does cast serious doubt on the underlying assumptions. It is arguable, at least, that even if use of a sentencing differential to induce guilty pleas were not permitted, existing judicial and prosecutorial resources would be sufficient to dispose of the criminal docket-either because most defendants would still plead guilty or because elimination of delaying tactics related to plea bargaining would free a greater part of these resources for trial, or both. However, even if prohibiting the use of a sentencing differential to induce guilty pleas meant that greater resources would be necessary to deal with the criminal docket, resort to methods that would not be condoned to induce waiver of other constitutional rights to induce defendants to waive the right to trial is not justified. There are a number of alternatives.

The most obvious, of course, is to provide an adequate number of

222 The disposition time for the average felony case went from 192 days to 89.5 days. While the "downward trend" in Anchorage started before the ban on plea bargaining and other factors, such as the appointment of a new Presiding Judge and the establishment of a master calendar contributed to this result, significant reductions in disposition time also occurred in Fairbanks and Juneau, where no such factors were present. See ALASKA STUDY, supra note 13, at 102-04, 274 (Table II-2). The report notes:

The Fairbanks reduction in processing time is especially interesting for two reasons: the policy against plea bargaining was most strictly enforced in that city, and the rate of trials rose most sharply there. Without any specific procedural reforms or personnel changes to acount for the acceleration, Fairbanks still became much more efficient.

Id. at 105 .

223 Id. at 103 . The study found that other effects of the prohibition of plea bargaining in Alaska were "more thorough case preparation by police and prosecutors, more painstaking factual and legal investigation by defense attorneys, and closer attention to calendar control by judges," id at 202, increased likelihood of conviction and imprisonment for certain felonies such as burglary, larceny, receiving stolen property, id. at 110-11, 179, 186-87, 190, and the imposition of more severe sentences in certain types of cases. Id. at 111, 227-29. Commenting on the situation before plea bargaining was prohibited, one prosecutor stated:

We had so few trials, we were afraid of them. It was a traumatic thing-its not easy to go in there and lose. I remember one prosecutor had eleven cases [set for trial] in one week. He hadn't even looked at one of the files. He dealt them all out on the last day, and he was proud of himself. I'm afraid we were giving away the farm too often. Id. at 11 .

224 The effect of prohibiting plea bargaining depends on a number of factors including such intangibles as the attitude of judges, prosecutors and defense attorneys and may, therefore, be different in each jurisdiction. Eveh in Alaska the impact was different in each of the three cities studied. See id. at 151-55. Moreover, although the ban on plea bargaining has been in effect in Alaska for five years, the statistical analysis only compared the year following the ban with the year preceding it. A long term study would, of course, be more persuasive. 
judges, prosecutors and supporting personnel. ${ }^{225}$ Arguments that the resources necessary to implement a constitutional provision are unavailable or too costly have been made with respect to other rights. The Court, however, has refused to accept such arguments as a justification for failure to accord other rights or for narrowly interpreting such rights. For example, the Court held unconstitutional a statute that limited appointment of counsel to offenses punishable by more than six months imprisonment, ${ }^{226}$ notwithstanding arguments that "in many sections of the country, there simply will not be enough lawyers available to meet this demand."227 Justice Powell, in a concurring opinion, urged a more flexible approach, noting the problems of "availability of counsel, of costs, and especially of intolerable delay in an already over-burdened system. . .."228 He made clear, however, that he did not think administrative considerations justified denial of constitutional rights. $\mathrm{He}$ stated, "[i]f I were satisfied that the guarantee of due process required the assistance of counsel in every case in which a jail sentence is imposed. . .I would not hesitate to join the Court's opinion despite my misgivings as to its effect upon the administration of justice."229 And similarly, Chief Justice Burger said over a decade ago: "[n]o one should challenge any expense to afford a defendant full due process and his full measure of days in court."230

Another solution may be to modify the existing process so as to provide with existing resources a trial for all those who request one. This solution would not require abandoning the adversary system, as has been urged.231 Much can be done to make the adversary system

225 See aba Standards Relating to the administration of Criminal Justice, Pleas of Guilty § 1.8, Comment:

These standards no longer express the view that it is permissible to grant charge and sentence concessions to defendants solely for purposes of processing cases through the system. The solution for crowded criminal dockets is the availability of sufficient personnel and other resources so that prompt trials can be readily given to all defendants who want them.

226 Argersinger v. Hamlin, 407 U.S. 25 (1972).

227 Id. at 56. (Powell, J., concurring). The Solicitor General, who urged adoption of the rule requiring counsel in all cases, recognized the far reaching consequences it would have in terms of expenses, backlog, and unavailability of counsel, and suggested the possibility of using clergymen, social workers, and others of that type as counsel. Id. Although Justice Douglas, who wrote the opinion for the Court, rejected the view "that the Nation's legal resources are [in]sufficient to implement the rule we announce today," citing statistics as to the large number of lawyers, id. at $37 \mathrm{n} .7$, he joined in Justice Brennan's concurring opinion which suggested the use of law students. Id. at $\mathbf{4 0}$.

$228 \mathrm{Id}$. at 62.

229 Id.

230 Burger, No Man Is An Island, 56 A.B.A.J. 325 (1970).

231 See Langbein, Torture and Plea Bargaining, supra note 4, at 21. See also L. WeINREB, Denial of Justice: Criminal Process in the United States 117 fols. (1977). 
more efficient. For example, until very recently, ${ }^{232}$ one alleging constitutional error in a state conviction could raise the same claim ten more times before it was disposed of with finality. ${ }^{233}$ Even if the claim was ultimately denied, a state attorney had to read the petition and write a reply and a court had to consider the petition and the reply and issue a decision at each level. If "the number of state prisoners who eventually win their freedom by means of federal habeas corpus" is "few indeed," as Justice Brennan stated in Fay $v . \mathrm{Noia}^{234}$ it is questionable whether devoting the substantial resources presently expended for post conviction review is justified, when the errors alleged have no bearing on guilt or innocence, ${ }^{235}$ particularly when the justification for denying a trial to determine guilt or innocence in the first instance is the lack of resources.

Another task that takes up a great deal of court time is determining the propriety of police conduct in investigating a crime and obtaining evidence. One might question the rationality of letting " $t]$ he criminal . . . go free because the constable has blundered." ${ }^{236}$ If the purpose of

232 Federal collateral review of state convictions has been limited recently. See Wainwright v. Sykes, 433 U.S. 72 (1977); Stone v. Powell, 428 U.S. 465.

233 A person convicted in a state court could generally (1) appeal as of right to a state intermediate court, (2) petition for leave to appeal to the state's highest court, (3) petition for certiorari to the United States Supreme Court, (4) make a motion for collateral review [coram nobis in New York] to the state trial court, (5) appeal to the state's intermediate court from the denial of the motion for collateral review, (6) petition for leave to appeal to the state's highest court, (7) petition for certiorari to the United States Supreme Court, (8) petition for a writ of habeas corpus to the United States district court, (9) petition for leave to appeal to the United States court of appeals from the denial of the petition for a writ of habeas corpus and (10) petition for certiorari to the United States Supreme Court. If the first two petitions for certiorari to the United States Supreme Court, no longer required in order to establish exhaustion of remedies, are omitted, that still leaves eight opportunities. Allegation of a different constitutional error starts the process all over again. When I clerked for a United States district judge, I saw seven petitions for habeas corpus from the same defendant. Justice Burger cited an example in which "more than fifty appellate judges reviewed the case. . .." Burger, supra note 230 , at 325 .

234372 U.S. 390,440 . Justice Brennan cited a 1958 study by the Administrative Office of the United States Courts that only 24 federal habeas corpus petitions providing for release of state prisoners had been granted in the preceding nine years and noted that the typical order under these circumstances permitted the state to retry the prisoner and, therefore, did not necessarily mean that the petitioner was ultimately released. Id. at 440-41 n.45. During the twelve month period ending June 30,1980, 10,744 habeas corpus petitions were filed in the U.S. district courts by federal and state prisoners. ADMINISTRATIVE OFFICE OF THE UNITED States Courts, AnN. Rep. 232 (Table 21) (1980). The report does not indicate how many were granted.

235 See Friendly, supra note 170 , at $148-49$.

236 People v. Defore, 242 N.Y. 13, 21, 150 N.E. 585, 587 (1926) (opinion by Cardozo, J.). Moreover, it isn't always the constable who blundered, see, e.g. , Coolidge v. New Hampshire, 403 U.S. 443, and it is sometimes impossible to determine whether he blundered until after the Supreme Court has decided the case. See, e.g., Spinelli v. United States, 393 U.S. 410 (1969). In Coolidge, the officers who conducted the search had obtained a warrant and there was no question that there was probable cause to issue it. The evidence was ruled inadmissible because the statute unconstitutionally provided for issuance of warrants by the Attorney 
the criminal law is to protect members of society from those who would violate their rights, letting the criminal go free because the constable blundered doubly defeats the purpose: it leaves the criminal free to continue to engage in crime $^{237}$ and it permits the offending police officer to remain in a position where he can continue to transgress constitutional safeguards. The desirability or efficacy of the exclusionary rules aside, ${ }^{238}$ if prosecutorial and judicial resources are inadequate, both history and reason support giving priority to the determination of the guilt or innocence of those charged with a crime. ${ }^{239}$ That determination has

General rather than by a court. It is difficult to see what the "constable" could have done differently, or how letting Coolidge, who was clearly guilty of murder, go free, would deter unlawful police conduct.

In Spinelli, the Supreme Court ruled four to three that the officer did not have probable cause to search. (Justice White concurred in the result and Justice Marshall took no part.) However, the judge who issued the warrant, the trial judge, six judges of the United States Court of Appeals for the Eighth Circuit, see 382 F.2d 871 (8th Cir. 1967) (en banc), and three Justices of the Supreme Court-a majority of all the judges who considered the questionbelieved there was probable cause. Again, it is difficult to see how the police officer could have known whether the search was permissible and how suppressing the evidence would deter unlawful police conduct. Some of the circuit courts have recently applied a good faith exception to the exclusionary rule and refused to suppress evidence even though the search was technically illegal where it would serve no deterrent purpose to do so, see United States v. Alvarez-Porraz, 643 F.2d 54 (2d Cir. 1981); United States v. Williams, 622 F.2d 830 (5th Cir. 1980) (en banc), and the Attorney General's Task Force on Violent Crime has recommended that "evidence should not be excluded from a criminal proceeding if it has been obtained by an officer acting in the reasonable, good faith belief that it was in conformity to the Fourth Amendment to the Constitution." ATtORney General's TASK FORCE ON ViOlent Crime-Final RePORT, 29 Crim. L. ReP. (BNA) 3131, 3134 (Aug. 19, 1981). See also Michigan v. De Fillippo, 443 U.S. 31 (1979); People v. Adams, 53 N.Y.2d 1, 422 N.E.2d 537 (1981).

237 Escobedo, whose conviction was reversed because he was not permitted to consult with his attorney prior to confessing, 378 U.S. 478 (1964), was subsequently arrested for other felonies. See N.Y. Times, Apr. 18, 1967, at 25, col. 7; N.Y. Times, July 13, 1966, at 5, col. 6.

238 There is considerable disagreement over whether the exclusion of illegally obtained evidence in fact deters unlawful searches and seizures. For a listing of recent articles on whether the empirical evidence proves or refutes that the exclusionary rule has a deterrent effect, see KAMISAR, supra note 129, at 222. Empirical studies following Miranda also differ on whether giving the warning has a significant impact on the number of confessions obtained. Compare Developments in the Law-Interrogation in New Haven, The Impact of Miranda, 76 YALE L.J. 1519 (1967) and Younger, Results of Survey Conducted in the District Attomey's Office of Los Angeles County Regarding the Effect of the Miranda Decision Upon the Prosecution of Felony Cases, 5 AM. CRIM. L.Q. 32 (1966), with Seeburger \& Wettick, Miranda in Pittsburgh-A Statistical Study, 29 U. PitT. L. Rev. 1, 23 (1967). For a discussion of the findings of these studies, see Kamisar, supra note 129 , at $631-35$.

The purpose of requiring a Miranda warning, of course, is not to deter confessions but to ensure that persons in a custodial setting are informed of their rights before any incriminating statements are elicited. Thus, a finding that confessions are equally forthcoming regardless of whether the warning is given or not, would remove any argument against requiring the warning. There is, however, also no reason for excluding the confession, and possibly freeing a dangerous criminal, where the warning was not given, or not given properly, if the confession would have been given even if the accused had been advised of his rights.

239 In addition to the right to trial itself, the right to an impartial judge and jury, the right 
been and is the primary purpose of criminal courts. It should not be supplanted by the use of the courts for other purposes.

Prosecutorial and judicial resources can also be conserved by streamlining various aspects of the trial, ${ }^{240}$ by providing a summary procedure for dealing with offenses that do not involve the possibility of incarceration or other serious penalties, ${ }^{241}$ and by decriminalizing conduct that can otherwise be regulated or that need not be regulated at all. ${ }^{242}$

Not everyone agrees that plea bargaining is a function of case pressure. 243 A study exploring the "adaptation of new prosecutors, defense attorneys, and judges to the plea bargain court," found that, though they "start with a presumption of trial," they ultimately adopt a "presumption of plea; they learn that $90 \%$ of defendants are guilty, that a

to counsel, the right to cross-examination, the requirement that guilt be established beyond a reasonable doubt, as well as numerous other rules of evidence, were all designed to that end.

240 For example, jury selection generally takes much less time in the federal courts than in some state courts, yet there is no evidence that state juries are better than federal juries. See Cleary, Jury Selection in a Federal Criminal Case, 26 PRAC. LAw. 37, 52 (No. 4 1980). See also N.Y. Times, Mar. 30, 1981, at A-1, col. 2:

Last year, the 18-20 judges in Manhattan Criminal Court held 386 misdemeanor trialsthe most since the early 1970's. In Washington, where six to eight judges sat, three times as many misdemeanor trials were held. The conviction rate in Manhattan-including pleas and guilty verdicts-was about 56 percent. In Washington it was 70 percent.

241 For example, a number of United States jurisdictions have removed from the criminal courts non-moving traffic violations. Philadelphia and Pittsburgh have an expedited trial system; only one-fourth of the convictions in Philadelphia and only one-third in Pittsburgh are on guilty pleas. See Alschuler, supra note 79, at 61 . In Germany, for certain crimes designated Vergehen, which involve only fines or restitution, a written order is sent to the accused setting forth the crime and the penalty and if he does not object within a specified period it becomes final. It is estimated that this system has been used in $70 \%$ of all criminal matters in which charges are filed. See Felstiner, Plea Contracts in West Germany, 13 LAW \& SOC. REV. 309, 310 (1979).

242 Public intoxication, sexual acts between consenting adults and use of addictive drugs are examples of conduct for which decriminalization has been suggested either on the ground that the particular conduct can be dealt with by other agencies of government or on the ground that they should not be regulated by government at all. Whether particular conduct should be decriminalized involves complex social and philosophical considerations beyond the scope of this article. For discussion of conduct "which has been declared criminal but for which criminal enforcement has proven either ineffective or unduly costly," see THE PRESIDENT'S COMMISSION ON LAW ENFORCEMENT AND ADMINISTRATION OF JUSTICE, TASK Force Report: The Courts 97-107 (1967). See also N.Y. Times, Oct. 19, 1980, at A-1, col. 1 , which reported that a study found that "more than 64 percent of the money spent each year by New York City's Criminal Court is 'wasted' by inefficiency" and that "more than 137,000 of the more than 235,000 [cases] filed in New York City Criminal Court in 1977should be removed from the Court system at the outset and diverted to alternate channels for processing. . . ."

243 See M. Heumann, Plea Bargaining: The Experiences of Prosecutors, Judges, AND Defense AtTorneys (1978). The assumptions on which Heumann based his conclusions as well as the conclusions are criticized in a review of the book by Barkai, Book Review 68 KY. L.J. 240, 244-45 (1979). 
sizeable portion of these have no substantive ground for contesting their guilt and that defendants are likely to be rewarded for a plea."244 Rather than supporting plea bargaining such findings argue against it. If ninety percent of those charged have no ground for contesting their guilt, a substantial percentage of those charged may plead guilty even in the absence of a "plea bargain."245 Establishing the guilt of those who do not should not be overly burdensome. Thus, there is no reason for rewarding these defendants for a plea. If plea bargaining is not necessitated by case pressure, then the major argument ${ }^{246}$ for penalizing those who claim innocence or who have some basis for contesting guilt and insist on a trial is eliminated.

\section{B. THE APPROACH IN OTHER COUNTRIES}

Since each country has different problems and a different system for the administration of criminal justice, no definitive conclusion can be drawn from the practice of other countries. It is nevertheless noteworthy that the use of promises or threats to induce a guilty plea has been rejected by other countries, both those that have the inquisitional system and those that have the adversary system. The German Criminal Code, for example, requires prosecution of all offenses "to the extent that there is a sufficient factual basis" 247 and mandates that every offense punishable by imprisonment go to trial. ${ }^{248}$ The English courts have ruled that if the court promises a lesser sentence for a plea ${ }^{249}$ or says anything which might erroneously give the appearance that it was entering into a bargain with the accused, ${ }^{250}$ the plea is vitiated. The court of appeal stated in Atkinson, "the appearance of justice is part of

244 HeumanN, supra note 243, at 156.

245 In Alaska the elimination of plea bargaining reduced guilty pleas only marginally. See notes 220-21 \& accompanying text supra. See also Krislov, Debating on Bargaining: Comments from a Synthesizer, 13 LAW \& Soc. REv. 573, 580 (1979).

246 Other arguments for imposing harsher sentences on those who are convicted after trial than on those who plead are that the latter are entitled to consideration because they save the government the time and expense of going to trial and that by pleading guilty they demonstrate repentance and therefore greater amenability to rehabilitation. These arguments are discussed in text accompanying notes 72-82 supra.

247 See Langbein, Land Without Plea Bargaining: How the Germans Do It, supra note 4, at 210. Prosecutorial discretion cannot be eliminated entirely, of course. A determination of whether the requisite factual basis exists in a particular case requires a judgment by the prosecutor. In addition, with respect to less serious offenses, the prosecutor may refuse to prosecute on " 'expediency grounds' (e.g., triviality of the offense, low culpability, danger to foreign relations, etc.)." Damaška, The Reality of Prosecutorial Discretion: Comments on a German Monograph, 29 AM. J. Comp. L. 119, 120, 122-24 (1981). See also K. DAvis, Discretionary Justice; A PrelimINARY INQUIRY 191-95 (1969).

248 See K. DAvis, supra note 247, at 194; Langbein, Land Without Plea Bargaining: How the Germans Do It, supra note 4, at 219.

249 Regina v. Turner [1970] 2 Q.B. 321.

250 Regina v. Atkinson, [1978] 2 All. E.R. 460 (C.A.). 
the substance of justice and it will not do if a prisoner or the general public derive the impression that it is possible . . . to achieve a bargain with the court."251 Admittedly, an empirical study found that covert plea bargaining still exists in England. ${ }^{252}$ The conclusion is, however, questioned by others. ${ }^{253}$ Moreover, it is one thing for a practice to occur despite its condemnation and quite another for the highest court of the land to permit and encourage it, as the United States Supreme Court has done. ${ }^{254}$

\section{Summary AND CONCluSion}

Over a decade ago, the President's Commission on Law Enforcement and the Administration of Justice noted that "[f]ew practices in the system of criminal justice create a greater sense of unease and suspicion than the negotiated plea of guilty."255 The National Advisory Commission on Criminal Justice Standards and Goals recommended that "negotiations between prosecutors and defendants - either personally or through their attorneys - concerning concessions to be made in return for guilty pleas should be prohibited." 256 However, with the exception of a few jurisdictions, ${ }^{257}$ plea bargaining, often accompanied by threats and promises, has continued to be the norm. The Supreme Court has sanctioned the use of promises of leniency to induce guilty pleas. ${ }^{258}$ It has sustained guilty pleas induced by fear of harsh penalties, including fear of the death penalty. ${ }^{259}$ It has also sustained the imposition of far more severe penalties on defendants who were convicted after refusing to plead guilty. ${ }^{260}$

As the preceding analysis has demonstrated, the Court's decisions in this area are inconsistent with its decisions in non-plea bargaining cases. While some of the inconsistencies might be explained on grounds

251 Id. at 462.

252 J. Baldwin \& M. McConville, Negotiated Justice: Pressures To Plead Guilty (1977). See also Baldwin \& McConville, supra note 79, at 296.

253 See Davis, Griffiths \& Napoleon, Bargain-Basement Justice: Judicial Responsibility for the Plea Bargaining System, 25 N.Y.L.S.L. REV. 319, 337-38 (1979).

254 See, e.g., Blackledge v. Allison, 431 U.S. 63; Santobello v. New York, 404 U.S. 257. See also note 66 \& accompanying text supra. I am, of course, not suggesting that plea bargaining should be made covert; only that the argument that it may not be possible to eliminate a practice completely should not become the justification for sanctioning it.

255 The President's Commission on LAW Enforcement and Administration of Justice, TASK Force Report: The Courts, supra note 242, at 9.

256 National Advisory Commission on Criminal Justice, Standards and Goals, STANDARD 3.1 (1973).

257 For some of these, see note 209 supra.

258 Santobello v. New York, 404 U.S. 257.

259 See text accompanying notes 93-106 supra.

260 See text accompanying notes 44-48 supra. 
other than the preservation of the plea bargaining process, others cannot. For example, it might be argued that the decision in Richardson ${ }^{261}$ was an attempt by Justice White, who had dissented in Harrison, ${ }^{262}$ to narrow Harrison. Even Brady ${ }^{263}$ and Parker ${ }^{264}$ might be explained as an attempt to narrow the principles declared in Noia ${ }^{265}$ and Jackson, ${ }^{266}$ rather than as an application of different constitutional standards to guilty pleas, since the composition of the Court had changed substantially in the interim. But no such argument can be made with respect to Perry ${ }^{267}$ and Bordenkircher. ${ }^{268}$ Bordenkircher and Perry were decided by the same Court. Indeed, the majority opinion was written by the same justice.

In rejecting challenges to plea bargaining, the Court has argued that the defendant's decision to plead is voluntary, that he is represented by counsel and, perhaps most importantly, that the plea is a reliable admission of guilt. While a plea induced by threats and promises may be voluntary under a broad definition of voluntariness, it is clearly not voluntary under the criteria used to determine voluntariness for other fifth amendment purposes, such as the admission into evidence of a defendant's extra-judicial statements. The presence of counsel has no bearing on the validity of requiring an accused to choose between a trial and a more severe penalty. Finally, while it is impossible to know whether or how many innocent persons plead guilty, a guilty plea is not necessarily a reliable indication of guilt. Depending on the sentencing differential in a particular case, a guilty plea may be the rational alternative even for an innocent defendant. Studies show that attorneys exert considerable pressure on their clients to plead, that many of those who plead guilty continue to assert their innocence, and that a significant proportion of those who plead guilty would not be convicted after trial. Moreover, none of these arguments deal with the contention that the imposition of higher sentences on those convicted after trials, the practice of many courts, violates the principle that the assertion of constitutional rights may not be penalized.

Commenting on the plea bargaining process in Roberts $v$. United States, ${ }^{269}$ Justice Marshall stated:

The Court has upheld that process on the theory that the relative equality

261 McMann v. Richardson, 397 U.S. 759 (1970).

262 Harrison v. United States, 392 U.S. 219.

263 Brady v. United States, 397 U.S. 742.

264 Parker v. North Carolina, 397 U.S. 790.

265 Fay v. Noia, 372 U.S. 391.

266 United States v. Jackson, 390 U.S. 570.

267 Blackledge v. Perry, 417 U.S. 21.

268 Bordenkircher v. Hayes, 434 U.S. 357.

269445 U.S. 552. 
of bargaining power between the prosecutor and the defendant prevents the process from being fundamentally unfair. But if the judge can be counted on to increase the defendant's sentence if he fails to cooperate, the balance of bargaining power is tipped in favor of the prosecution. ${ }^{270}$

Justice Marshall's reference to the defendant's failure to cooperate concerned his refusal to give the government information about others in the criminal enterprise. However, the same reasoning applies to plea bargaining in general. If the Court has indeed upheld plea bargaining on the theory of "relative equality of bargaining power" between the defendant and the prosecutor, and in the belief that the judge would not "increase the defendant's sentence if he fails to cooperate," as Justice Marshall states, it has done so under a misconception. It should be clear by now that no such equality exists and that in a substantial portion of cases "the Judge can be counted on to increase the defendant's sentence" if he fails to plead. ${ }^{271}$

The generally held belief that prohibiting the use of plea bargaining would overwhelm the criminal justice system, which the justices of the Supreme Court apparently share, is premised on factual assumptions that have not been tested and is not supported by the experience of those jurisdictions that have limited or prohibited plea bargaining. The experience of Alaska, the one state that has prohibited use of a sentencing differential or charge reduction to induce pleas, was that "curtailment of plea bargaining did not in any way impede court efficiency, it had the contrary effect." 272

If it is true that the existing system for the administration of criminal justice could not function once plea bargaining was prohibited, it raises serious questions about the desirability of that system. One must ask whether perpetuating a system which is so complex and costly is justified when that system can only exist by denying the rights it deems most important to over ninety percent of those subjected to it. If, on the other hand, it is not essential to use threats and promises to induce those charged with crimes to forfeit their rights, then the practice should be prohibited. ${ }^{273}$ In either case, the Court should not subvert its own

$270 \mathrm{Id}$. at 568 (citation omitted).

271 See notes $42-43$ \& accompanying text supra. See also Frank v. Blackburn, 610 F.2d 383 (5th Cir. 1980) upholding a 33 year sentence following trial, even though defendant was promised a 20 year sentence if he pleaded.

272 Alaska STUdy, supra note 13, at 103.

273 Views on the desirability of eliminating plea bargaining, unlike views on some other issues in the administration of criminal justice, do not depend on whether one thinks it more important to protect society from criminals or more important that government not deny those charged with crime the protections provided for by the constitution. The plea bargaining process impedes both. Plea bargaining has been criticized as a denial of constitutional rights, see, e.g., Kaplan, supra note 13; Wilson, supra note 184; Note, supra note 10, and as detrimental to effective law enforcement and rehabilitation. See, e.g., REPORT OF THE NEw 
precedents or draw distinctions that are analytically untenable in order to sustain a practice that is clearly inconsistent with fundamental principles of constitutional law.

York State Special Commission on Attica: Attica (1972) (hereinafter cited as AtTICA); Arcuri, Police Perceptions of Plea Bargaining: A Preliminary Inquiry, 1 J. POLICE SCI. \& AD. 93 (1973); Dean, The Illegitimacy of Plea Bargaining, 38 Fed. PROB. 18 (No. 3 1974). The Report of the Commission on Attica states that, "what makes inmates most cynical about their preprison experience is the plea-bargaining system" and reiterates the warnings of the Joint Legislative Committee on Crime that "no program of rehabilitation can be effective on a "prisoner who is convinced in his own mind that he is in prison because he is the victim of a mindless, undirected and corrupt system of justice." ATTICA, supra, 30-31 (1972), quoted in Kamisar, supra note 129, at 1233. The Police Commissioner of New York stated:

[W] hat happened to last year's 94,000 felony arrests? Exactly 552 of them went to trial, 552 out of 94,000 . The rest of them were disposed of. Disposed of means dismissed outright, reduced to misdemeanors via plea-bargaining, reduced to much lesser felonies via plea-bargaining. No doubt certain of the honest, dedicated policemen who made these 94,000 arrests last year came to the belief that conscientious police work is a waste of time, a waste of effort and a waste of devotion.

N.Y. Times, Mar. 24, 1972, at 41, col. 2. See also N.Y. Times, Mar. 16, 1981, at B-3, col. 4 ("[a]ccording to recent Police Department statistics, the chance that a felony arrest will end in a sentence to a state prison is about one to 108 . The police have put much of the blame on prosecutors, contending that they too readily reduce some felonies to misdemeanors. . . .") Thus, the elimination of plea bargaining should be favored by those interested in better law enforcement as well as by those interested in protecting individual rights. 